\title{
PHYSICAL, CHEMICAL AND ISOTOPIC CHARACTERISTICS OF GROUNDWATER AND SURFACE WATER IN THE LAKE CHILWA BASIN, MALAWI
}

\author{
By \\ CHARLES MISSI \\ Bachelor of Education in Science \\ The University of Malawi \\ Zomba, Malawi \\ 2006
Submitted to the Faculty of the Graduate College of the Oklahoma State University in partial fulfillment of the requirements for the Degree of MASTER OF SCIENCE \\ May 2018
}


PHYSICAL, CHEMICAL AND ISOTOPIC

CHARACTERISTICS OF GROUNDWATER AND SURFACE WATER INTHE LAKE CHILA BASIN,

MALAWI

Thesis Approved:

Dr. Eliot Atekwana

Thesis Adviser

Dr. Mohamed Abdelsalam

Dr. Javier Vilcaez 


\section{ACKNOWLEDGEMENTS (Optional)}

I sincerely thank my advisor Dr. Eliot Atekwana for the time spent patiently guiding me in laboratory work and in writing. You took time out of your busy schedule to help me and provide me with valuable insights in the writing process. I also like to thank my committee members Dr. Mohamed Abdelsalam and Dr. Javier Vilcaez. My appreciation to Dr. Mohamed for your advisory role as the Graduate Student Advisor. You kept reminding me of my obligations as a graduate student to meet up with deadlines for graduate study.

I thank Dr. Tao Wu the lab technician for the geochemistry laboratory for assisting with sample analyses.I thank Dr. Andrew Katumwehe, Mercy Achang and Dr. Leonard Kalindekafe for your timely encouragement and reminders of my ultimate goal.

I also thank the Government of Malawi for the sponsorship through the World Bank-funded project, Malawi Growth and Governance Support Project (MGGSP) who supported me in the first half and the French-funded project, Geological Mapping and Mineral Assessment Project (GEMMAP) who supported me in the last half of my study at Oklahoma State University (OSU).

My Gratitude also goes to the Director of the Geological Survey of Malawi Mr. Jalf Salima for permitting me to pursue a graduate degree course.

I thank my friends Babak Shabani, Pouyan Ebrahimi, Chikondi Chisenga, Annock Chiwona, John Ng'ombe, Burnet Msika, and Victor Nyalugwe; the past two years would have been infinitely harder without your constant support and encouragement.

iii

Acknowledgements reflect the views of the author and are not endorsed by committee members or Oklahoma State University. 
Name: CHARLES MISSI

Date of Degree: May, 2018

Title of Study: PHYSICAL, CHEMICAL AND ISOTOPIC CHARACTERISTICS OF GROUNDWATER AND SURFACE WATER IN THE LAKE CHILWA BASIN, MALAWI

Major Field: Geology.

\begin{abstract}
We measured the physical, chemical and isotopic properties of groundwater, streams and Lake Chilwa in the Lake Chilwa Basin in southern Malawi. Our goal was to assess water quality and identify the hydrogeochemical processes that control water quality. Groundwater in the Lake Chilwa Basin are highly saline which has led to water shortages because of poor water quality. We hypothesized that the highly saline groundwater resulted from water-rock interaction. The objective of the study was to assess the chemical evolution of the groundwater and surface water and their relationship to water-rock interactions. Groundwater from 16 boreholes, 5 stream water samples and 3 samples from Lake Chilwa were collected using standard methods and investigated for temperature, $\mathrm{pH}$, electrical conductivity, total dissolved solids (TDS), major ions and stable isotopes of hydrogen and oxygen. Groundwater and Lake Chilwa water had higher ionic concentrations (e.g., $\mathrm{HCO}_{3}{ }^{-}, \mathrm{Na}^{+}, \mathrm{Ca}^{2+}, \mathrm{Mg}^{2+}$ ) than stream water. Ionic evolution models indicate weathering of silicate minerals as the major control of the ionic concentrations. The chemistry of water in the Lake Chilwa is markedly affected by evaporation. Concentrations of the TDS, $\mathrm{HCO}_{3}^{-}$ and $\mathrm{Cl}^{-}$in many locations are above the recommended limits prescribed for drinking water by the World Health Organization (WHO). The results of this study show that the poor water quality is due to natural water-rock interactions. Because quality of streams water is adequate, and because base flow to perennial streams is supported by shallow groundwater, efforts should be made to map shallow fresh groundwater aquifers for domestic and industrial use.
\end{abstract}




\section{Table of Contents}

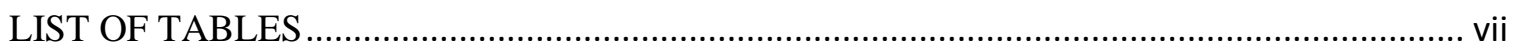

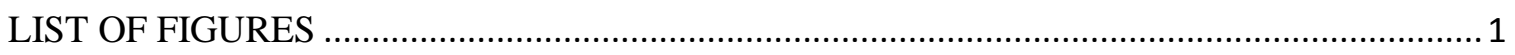

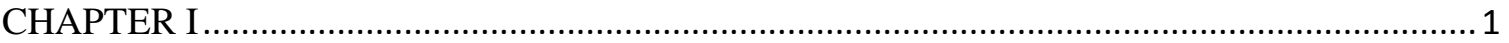

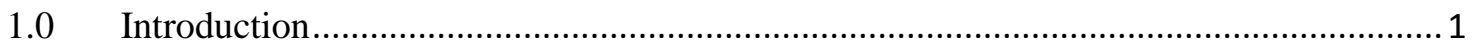

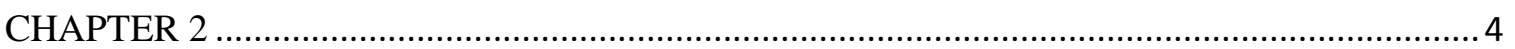

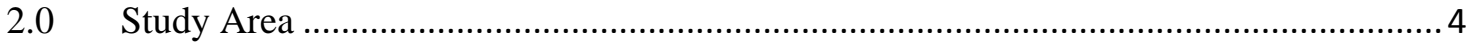

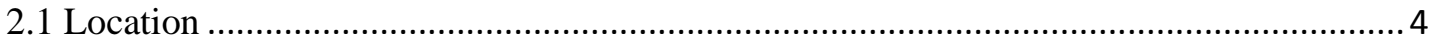

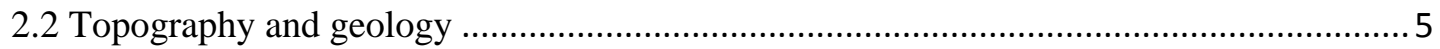

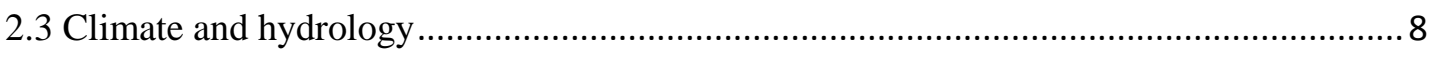

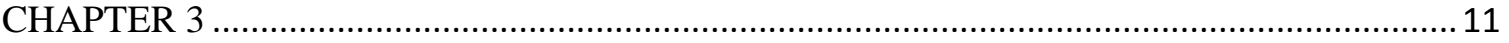

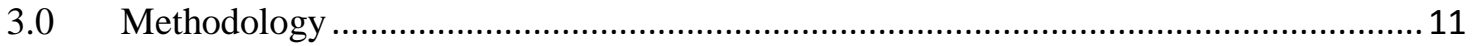

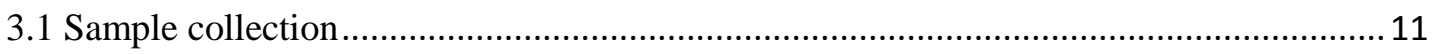

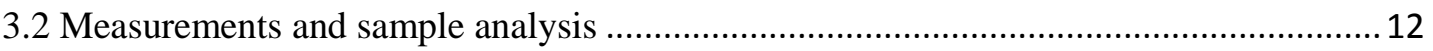

3.3 Determination of water types and mineral saturation indices ...................................... 13

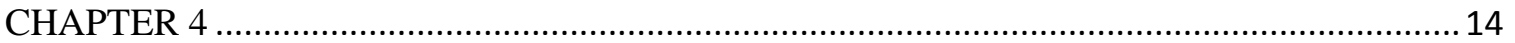

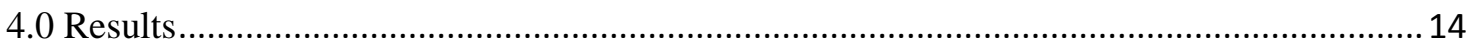

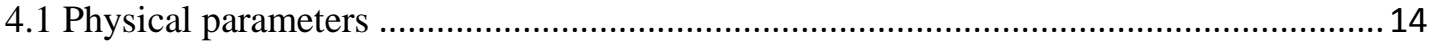

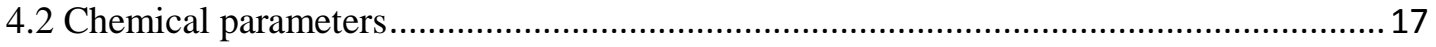

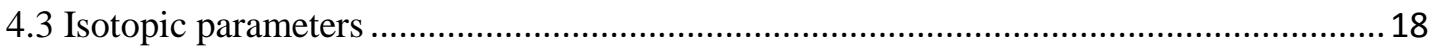

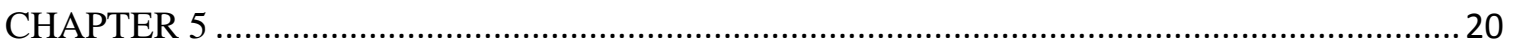

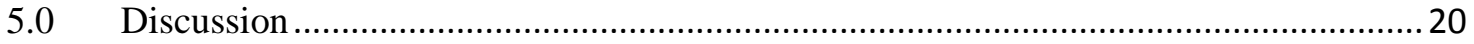

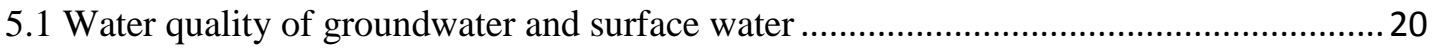

5.2 Processes responsible for groundwater and surface water quality .................................27

5.4 Carbonate evolution of groundwater and surface water ................................................. 36

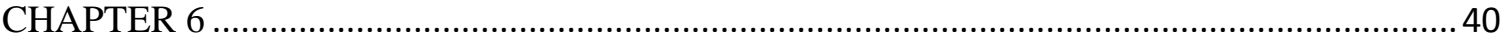




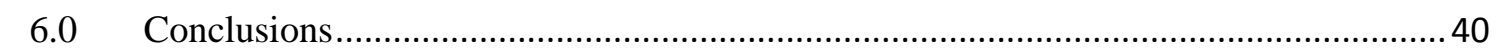

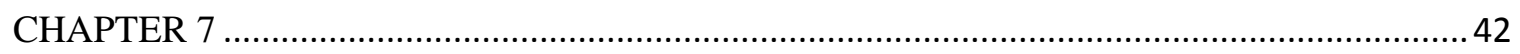

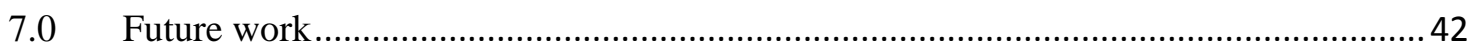

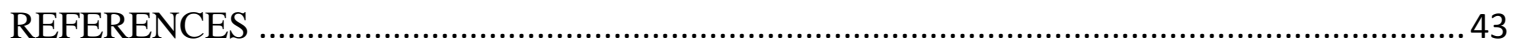

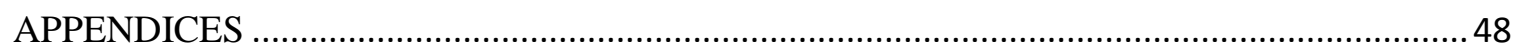

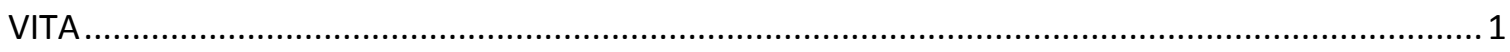




\section{LIST OF TABLES}

Table 1: Summary statistics of the physical and chemical compositions of water samples. All values are in $\mathrm{mg} / \mathrm{L}$ except $\mathrm{pH}$, temperature $\left({ }^{\circ} \mathrm{C}\right), \mathrm{EC}(\mu \mathrm{S} / \mathrm{cm})$ and oxygen and hydrogen isotopes (\%o). GW is groundwater, LW is lake water, SW is stream water, Minis minimum value, Max is maximum value and SD is the standard deviation.

Table 2: Results of the physical, chemical and isotopic analyses of water samples from Lake Chilwa Basin ( - = not measured) 16

Table 3: Water Quality Standards. WHO Drinking Water Guidelines (WHO, 2008) and Malawi bureau of standards (MBS, 2005)maximum permissible levels....................................................... 20 


\section{LIST OF FIGURES}

Figure 1 Map of Malawi showing river drainage; the solid rectangle is the location of the study area. The map shows Lake Chilwa and groundwater and surface water sampling locations. Shape files provided by Geological Survey Department, Malawi. .................. 5

Figure 2:Digital elevation map of the study area. Source: ETOPO1 Global Elevation data. ........ 6

Figure 3:Geological map of the study area. Source: Geological Survey Department of Malawi.. 8

Figure 4: Plot of concentrations of total dissolved solids (TDS) for groundwater and surface water in the Lake Chilwa Basin. Also shown on the plot is a line representing World Health Organization (WHO) maximum permissible concentrations in drinking water (WHO 2008).

Figure 5: Plots of concentrations of cations (a) $\mathrm{Na}^{+}$and (b) $\mathrm{K}^{+}$for groundwater and surface water in the Lake Chilwa Basin. Also shown on the plot is a line representing World Health Organization (WHO) maximum permissible concentrations in drinking water (WHO, 2008).

Figure 6: Plots of concentrations of (a) $\mathrm{F}^{-}$(b) $\mathrm{Cl}^{-}$, (c) $\mathrm{NO}_{3}{ }^{-}$, and (d) $\mathrm{HCO}_{3}{ }^{-}$for groundwater and surface water in the Lake Chilwa Basin. Also shown on the plots are lines representing World Health Organization (WHO) maximum permissible concentrations in drinking water (WHO, 2008).

Figure 7:Cross plot of isotopic composition of (a) oxygen $\left(\delta^{18} \mathrm{O}\right)$ vs. hydrogen $\left(\delta^{2} \mathrm{H}\right)$. Also plotted is the Global Meteoric Water Line (GMWL) and the local evaporation water line (LEWL) and (b) Cross plot of isotopic composition of Total dissolved solids (TDS) vs. $\delta^{18} \mathrm{O}$. for groundwater and surface water in the Lake Chilwa Basin.

Figure 8: Piper plot showing ionic proportions for groundwater and surface water in the Lake

Chilwa Basin

Figure 9: Cross plots of $\mathrm{Ca}^{2+}$ vs. $\mathrm{HCO}_{3}{ }^{-}$for groundwater and surface water in the Lake Chilwa Basin.

Figure 10: Cross plots of $\mathrm{Ca}^{2+}+\mathrm{Mg}^{2+}$ vs. $\mathrm{HCO}_{3}$ for groundwater and surface water in the Lake Chilwa Basin.

Figure 11: Cross plot of $\mathrm{Na}^{+}$vs. $\mathrm{HCO}_{3}{ }^{-}$for groundwater and surface water in the Lake Chilwa Basin.

Figure 12:Cross plots of (a) $\mathrm{Ca}^{2+}$ vs the saturation index for calcite ( $\mathrm{SI}_{\text {calcite }}$ ) and (b) $\mathrm{Ca}^{2+}+\mathrm{Mg}^{2+}$ vs. saturation index for dolomite ( $\left.\mathrm{SI}_{\text {dolomite }}\right)$ for groundwater and surface water in the Lake Chilwa Basin

Figure 13:Cross plot of $\mathrm{pH}$ vs. $\mathrm{pCO}_{2}$ of for groundwater and surface water in the Lake Chilwa Basin 


\section{CHAPTER I}

\subsection{Introduction}

Globally, groundwater and surface water are the major sources of water for domestic, agricultural and industrial purposes. Approximately one third of the world's population use groundwater for domestic use (Nickson et al., 2005). The World Health Organization (WHO) (2004) report that having safe drinking water is an internationally accepted human right. However, groundwater resources are under constant threat of salinization which is a worldwide concern (Rajmohan et al., 1997; Dar et al., 2011; Ebrahimi and Vilcáez, 2018a\&b).

Groundwater and surface water in rural areas of Malawi are the source of water for domestic use (Southern Africa Development Corporation (SADC), 2002). A report by the British Geological Survey (BGS) (2004) indicates that groundwater in some parts of Malawi is characterized by high salinity as a result of evaporative concentration or dissolution of evaporative minerals in sedimentary rocks. The occurrence of groundwater with high salinity in southern Malawi is a major water quality problem (Davis, 1969; Monjerezi, 2011). The Lake Chilwa Basin in southern Malawi has saline ground water and surface waters and water use is impaired by high concentrations of solutes (Food and Agricultural Organization (FAO), 2005). Boreholes which tap groundwater with high salinity are frequently abandoned in favor of open unprotected shallow hand dug holes in 
dry river beds or surface water (Bath, 1980). High levels of other physico-chemical and microbiological parameters (EC, TDS, turbidity, fecal coliform and fecal streptococci) at several sites suggest that the water sources are grossly contaminated with bacteria, hence not suitable for human consumption without treatment (Chidya et al., 2016).However, the expansion of groundwater supplies countrywide and the improvement of drinking water quality remains a national priority (Government of Malawi (GOM), 1995).

Previous investigations of the quality of groundwater and surface water in the Lake Chilwa Basin focused on determining the physical properties and concentrations of chemical and biological pollutants and their conformance with WHO and Malawi Bureau of Standards (MBS) drinking water quality guidelines (Saka and Ambali, 1999;Palamuleni, 2002; Msonda et al., 2007; Hellen, 2013).Although borehole supplies are used by a significant percentage of the population in Malawi, information on the chemical composition of the water in these boreholes is either scanty or non-existent (Bath, 1980; Chilton and Smith Carington, 1984; Mc Farlane and Bowden, 1992; Kanyerere, et al., 2010; Palamuleni, 2002; Sajidu et al., 2008; Chidya et al., 2016).There are no dedicated studies on the hydro-geochemical properties designed to understand the processes that add solutes into or remove solutes from groundwater and surface water in the Lake Chilwa Basin.

Geochemical processes occurring within the groundwater and surface water and reactions with aquifer minerals have a profound effect on water quality. These geochemical processes are responsible for the temporal and spatial variations in groundwater and surface water chemistry. Where there are marked and temporal variations in the physical and 
chemical properties of groundwater and surface water, tracing these changes relative to the water cycle is instructive in understanding the chemical evolution. Stable oxygen $\left(\delta^{18} \mathrm{O}\right)$ and hydrogen isotopes $(\delta \mathrm{D})$ have proven very useful in tracing the water cycle and in the understanding of hydro-chemical evolution of groundwater and surface water (Gat and Tzur, 1968; Fontes et al., 1980).

The $\delta^{18} \mathrm{O}$ and $\delta \mathrm{D}$ of water can be used as an effective tracer of rain recharge, groundwater flow, water-rock interaction and evaporative processes (e.g., Fritz and Clark, 1997). The fact that the previous studies in the Lake Chilwa Basin did not use stable isotopes of water and hydro-geochemical processes to understand the chemical evolution of water in relation to water quality is a major knowledge gap in our understanding of the origin of water quality in the Lake Chilwa Basin.

The overarching goal of this study is to understand the origin of water quality in the Lake Chilwa Basin, by developing a fundamental understanding of the dominant geochemical processes responsible for groundwater and surface water quality. We hypothesize that highly saline groundwater in the Lake Chilwa Basin results from water-rock interactions. The objective of this study was to assess the origin of the quality of groundwater and surface water from physical, chemical and isotopic properties. We used a combination of the physical properties, the major ion concentrations and $\delta^{18} \mathrm{O}$ and $\delta \mathrm{D}$ of water and their relation to water-rock interaction to fulfill our objective.

The results of this study is useful to bridge the information gap needed in addressing groundwater and surface water quality, as well as providing a foundation for groundwater monitoring. Groundwater monitoring is important as it provides groundwater quality 
information, such as identification of specific chemical species and associated concentrations that impair groundwater and surface water quality. Such information can help decision makers better understand the water quality and their potential effects on public health and the ecosystem, and how to address issues of water quality impairment. 


\section{CHAPTER 2}

\subsection{Study Area}

\subsection{Location}

Lake Chilwa Basin (latitude $15^{\circ} 20^{\prime} \mathrm{S}$, longitude $35^{\circ} 40^{\prime} \mathrm{E}$ ) is a close basin of about $7500 \mathrm{~km}^{2}$ located in the southern Malawi and includes portion of north eastern Mozambique as shown in Figure 1.

The Lake Chilwa Basin covers three administrative districts: Phalombe has about 73,880 hectares, Machinga has about 11,200 hectares and Zomba has about 185,174 hectares of land (Sagona, 2016). The Lake Chilwa Basin is bounded to the west by the Chikala Hills, Zomba and Malosa Mountains, the Shire highlands and Chiradzulu Mountain. These highlands give rise to the Domasi River, Likangala River, Thondwe River and Namadzi River. The basin is bounded to the south-east by the Mulanje and Michesi mountains which give rise to the Phalombe River and Sombani River. To the east lie the hills and mountains of Mozambique which give rise to Mnembo River and Mbugwe River (Njaya, 2011). Among the seven rivers only Domasi River and Likangala River are perennial, the rest dry up during the dry season. 


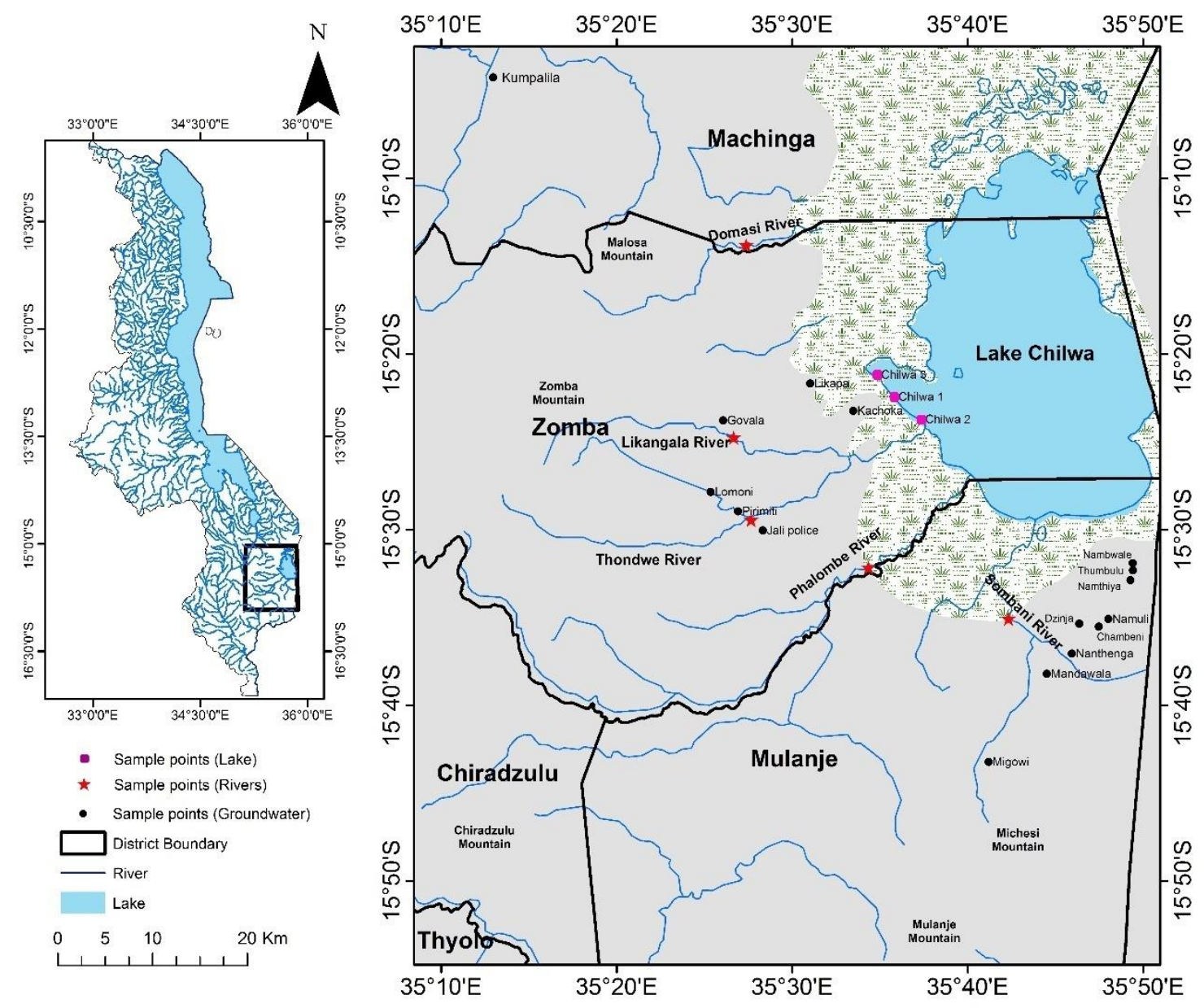

Figure 1 Map of Malawi showing river drainage; the solid rectangle is the location of the study area. The map shows Lake Chilwa and groundwater and surface water sampling locations. Shape files provided by Geological Survey Department, Malawi.

\subsection{Topography and geology}

The topography of the Lake Chilwa Basin is made up of uplands and lowlands (Figure2).

The Lake Chilwa Basin is a tectonic depression of post-cretaceous age that has been progressively filled with sand, silt and various sediments from the denudation of the surrounding highlands (Sagona, 2016).The uplands have deep, well drained sandy soils 
derived from the weathering of gneisses, while the lowlands have very deep soils with variable drainage in fluvial, colluvial and lacustrine deposits (Morgan and Kalk, 1970).

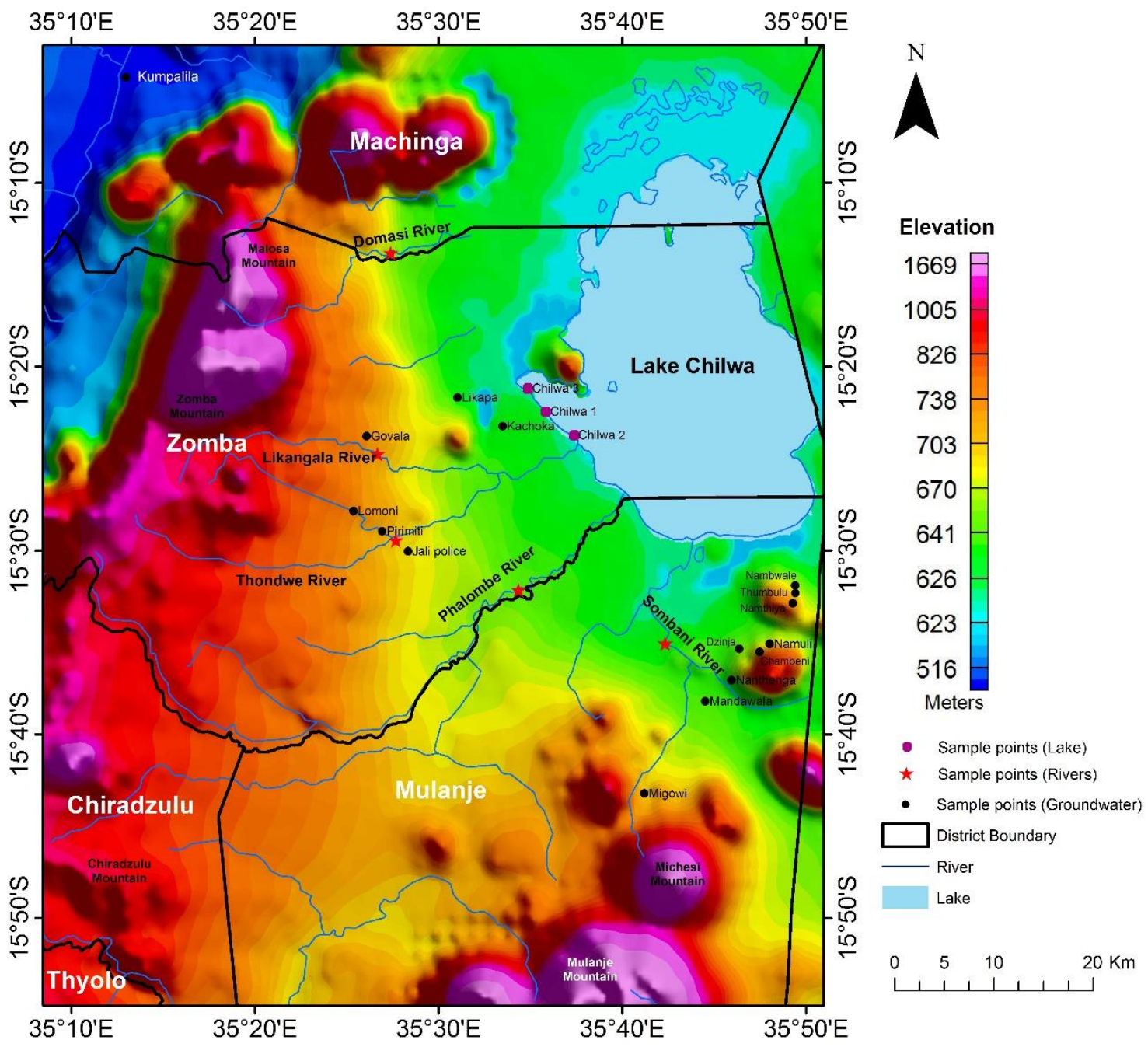

Figure 2:Digital elevation map of the study area. Source: ETOPO1 Global Elevation data.

The Lake Chilwa Basin as shown in Figure 3 is characterized by (1) crystalline metamorphic and igneous rocks of Precambrian to lower Paleozoic age referred to as the basement complex (Carter and Bennett, 1973; Chilton and Smith-Carington, 1984; Mapoma and Xie, 2014). The major lithological units of the basement complex are 
charnockites and granulites. Charnockites include orthopyroxene granite, quartz, feldspar, syenite and others, whereas granulites include pyroxene, biotite, garnet, calcium plagioclase and quartz, (2) the Chilwa alkaline intrudes the Precambrian basement and is divided into 4 lithological units: basanite, granite and syenite, nepheline syenite and carbonatite. Nepheline syenite (sodium potassium aluminosilicate) consists largely of nepheline and alkali feldspars which include microcline, albite, mica, hornblende and magnetite.

Carbonatites consists of calciocarbonate, magnesiocarbonate and ferrocarbonate, (3) Cenozoic sediments consisting of alluvial fans and lacustrine sediments. Intrusions of carbonatites in the Chilwa Alkaline Province have formed features that define the topographic ring complex of Zomba and Mount Mulanje (Swanzie and Stubbs, 1972). The study by Swanzie and Stubbs (1972) show that the carbonatites contain rare earth elements, apatite, limestone and marble. Bloomfield (1965) states that the major rock types of the Lake Chilwa Basin are charnockitic gneiss and granulite. These rocks are characterized by the development of north-north-east (N-N-E) trending foliations. 


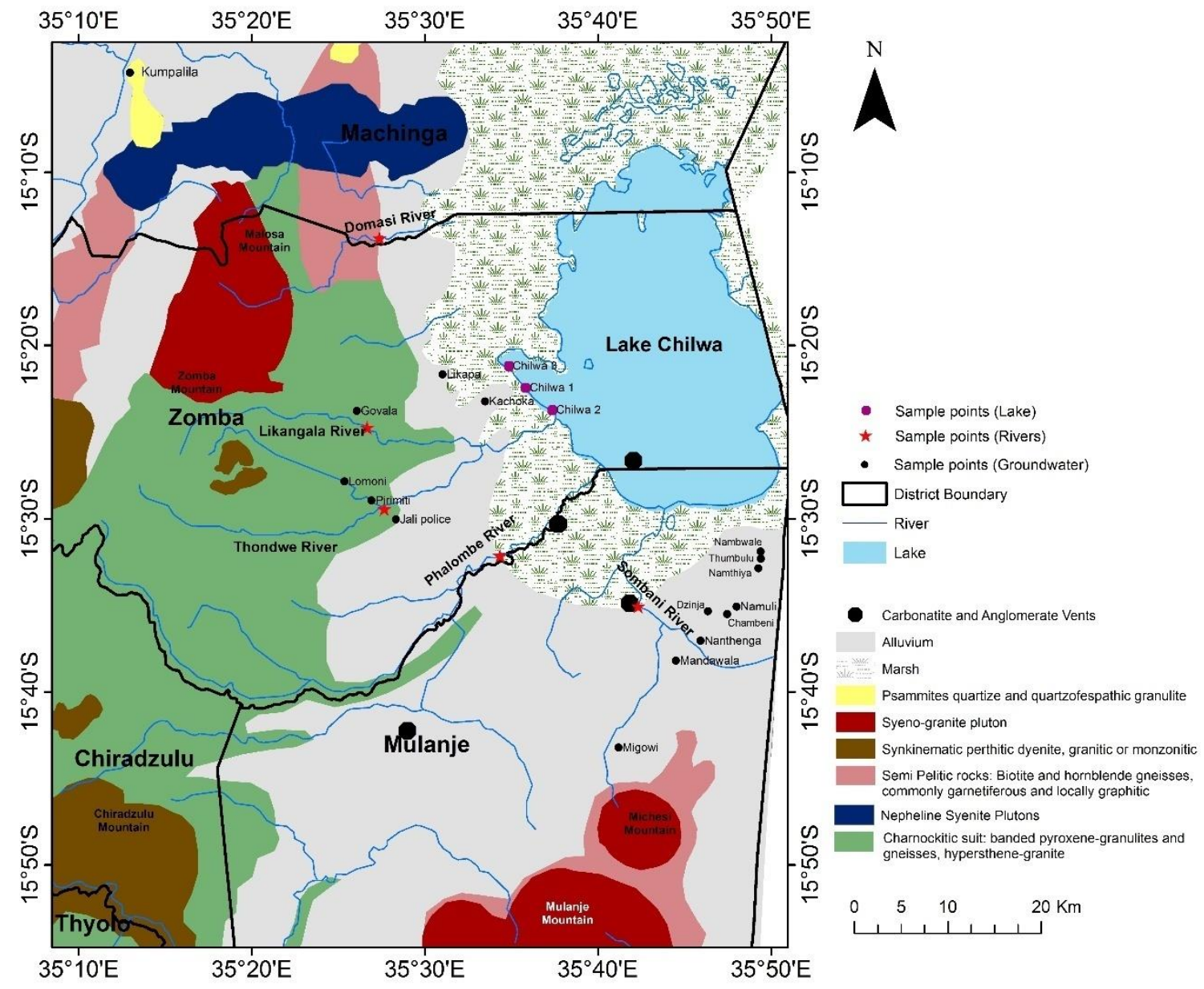

Figure 3: Geological map of the study area. Source: Geological Survey Department of Malawi.

\subsection{Climate and hydrology}

The Lake Chilwa Basin experiences a warm tropical climate, which is characterized by rainy and dry seasons. The rainy and dry seasons occur from November to April and May to October, respectively. The mean annual temperature is $24^{\circ} \mathrm{C}$. The highest temperature of $29^{\circ} \mathrm{C}$ and the lowest temperature of $20^{\circ} \mathrm{C}$ are experienced in October and June, respectively (Government of Malawi (GOM), 2010). 
Rainfall variability has a significant impact on water availability and the discharge particular catchments (McCarthy et al., 2001; Bloomfield, 2002; Ngongondo, 2006; Mapoma and Xie, 2014). However, processes other than rainfall play a significant role in the hydrologic processes of any catchment (Ngongondo, 2006). The numerous rivers, lakes, dams, lagoons and marshes existing in Malawi (GOM, 2011) connect with groundwater in either recharge zones or in discharge zones.

The drainage pattern of the Lake Chilwa basin is radial (Figure 2) (Lancaster, 1981).Lake Chilwa is at an altitude of $650 \mathrm{~m}$ above mean sea level (amsl). The maximum depth of the lake is $2.7 \mathrm{~m}$ and the lake surface measures $1759 \mathrm{~km}^{2}$. There are six major influent rivers draining into Lake Chilwa: the Domasi, Likangala, Thondwe, Phalombe, Sombani and Mnembo with maximum discharges which occur during the rainy season of December to April, usually peaking in February (Lancaster, 1979). The Mnembo River flows from Mozambique into Lake Chilwa and is actually the lake's largest source of water (Jamu et al., 2003).

The aquifers hosting groundwater in the Lake Chilwa Basin include the deeper basement aquifers and shallow sedimentary alluvial aquifers (Mapoma and Xie, 2014). The basement aquifers are low yielding because of the less porous nature of igneous and metamorphic rocks that do not allow a lot of water to pass through them whereas shallow alluvial aquifers are high yielding. The water table is closer to the surface in the valley region and deeper in higher elevations (Mkandawire, 2004). Borehole yields are highest where saturated thickness of the weathered zone is greatest (Chilton and Smith-Carington, 1984). In general, however, the weathered basement aquifer produces low groundwater yields 
(GOM, 2007; Chilton and Smith-Carington, 1984). On the other hand, shallow alluvial aquifers are high yielding with recorded yields in excess of $10 \mathrm{~L} / \mathrm{s}$ (Chimphamba et al., 2009; GOM, 2007). Mc Farlane et al. (1992) observed and concluded that very flat land at least one kilometer from the hill or mountain is generally likely to be high yielding than sites close to the hill. In terms of chemistry, the shallow aquifers are less mineralized than the deeper aquifers (Mc Farlane and Bowden, 1992). Groundwater is of variable qualities and quantities, unevenly distributed in time and space (GOM, 2007). Aquifer recharges from broad interfluves and groundwater discharges in surface depressions. 


\section{CHAPTER 3}

\subsection{Methodology}

\subsection{Sample collection}

Water samples were collected from boreholes, streams and Lake Chilwa using standard sampling procedures (APHA, 1985). Water sample collection was conducted from $20^{\text {th }}$ December, 2016 to $2^{\text {nd }}$ January, 2017. Groundwater samples were collected from the following boreholes: Dzinja, Namthiya, Nthumbulu, Nambwale, Namuli, Chambeni, Nanthenga, Mandawala, Migowi, Likapa, Govala, Kachoka, Pirimiti, Jali police, Lomoni and Kumpalila (Figure1). Groundwater samples were collected by hand pumping after purging three estimated casing volumes.

All stream water samples were collected in easily accessed points (e.g., under bridges) from the following streams: Domasi, Likangala, Thondwe, Phalombe and Sombani. Lake water samples were collected from the western side of Lake Chilwa along the shore from three locations (Figure1). Stream water and lake water samples were collected using grab technique. 
All water samples were filtered through a $0.45 \mu \mathrm{M}$ nylon filter during collection. The sample bottles were rinsed three times with the filtered water sample to be collected and then filled and capped. Filtered water for cations analysis were collected in $60 \mathrm{~mL}$ polypropylene bottles, acidified to a $\mathrm{pH}<2$ with high purity nitric acid (Apha, 1989), and stored in cooler box. Samples for anions and silica analyses were collected unacidified in $30 \mathrm{~mL}$ polypropylene bottles and stored in a cooler box. Water samples for dissolved inorganic carbon(DIC) were collected using syringes and introduced into septum tubes preloaded with $1.5 \mathrm{~mL}$ of $85 \%$ phosphoric acid and magnetic stir bars as described by Atekwana and Krishnamurthy (1998).

\subsection{Measurements and sample analysis}

Water temperature, $\mathrm{pH}$, electrical conductivity (EC) and total dissolved solids (TDS) were measured in situ at each borehole during purging using potable multi-meter probe (HANNA instrument model $991300 \mathrm{~N}$ ). The probe of the meter was dipped in the container receiving the pumped water and readings were taken after stabilization (Apha, 1989). For surface water, the probe was immersed in the water and readings are recorded after stabilization.

In the field, alkalinity was determined by $\mathrm{H}_{2} \mathrm{SO}_{4}$ titration to an acid equivalent point of 4.2 using a digital titrator (Hatch Company, 1992). Dissolved silica was measured using heteropoly blue chemistry to determine the "molybdate reactive" silica and measured with a CHEMetrics V-2000 Photometer at $815 \mathrm{~nm}$ (CHEMetrics, 2012). In the laboratory, major anions and cations $\left(\mathrm{F}^{-}, \mathrm{Cl}^{-}, \mathrm{SO}_{4}{ }^{2-}, \mathrm{NO}_{3}{ }^{-}\right.$and $\left.\mathrm{Na}^{+}, \mathrm{K}^{+}, \mathrm{Ca}^{2+}, \mathrm{Mg}^{2+}\right)$ were determined by ion

chromatography. Dissolved inorganic carbon concentrations were determined by 
extraction and cryogenic purification of carbon dioxide $\left(\mathrm{CO}_{2(\mathrm{~g})}\right)$ using a vacuum line and $\mathrm{CO}_{2(\mathrm{~g})}$ (Atekwana and Krishnamurthy, 1998). Stable isotopes of hydrogen and oxygenanalysis of water samples was done using Off Axis-Integrated Cavity Output Spectroscopy (OA-ICOS) manufactured by Los Gatos and sold as the Triple Liquid Water Analyzer. Stable isotopes ratios for hydrogen and oxygen are reported in the delta $(\delta)$ notation in per mil (\%o):

$$
\delta(\%)=\left(\left(\mathrm{R}_{\text {sample }} / \mathrm{R}_{\text {standard }}\right)-1\right) X 1000
$$

where $\mathrm{R}$ is ${ }^{2} \mathrm{H} /{ }^{1} \mathrm{H}$ or ${ }^{18} \mathrm{O} /{ }^{16} \mathrm{O}$. The $\delta$ values for $\mathrm{H}$ and $\mathrm{O}$ isotopes are reported relative to the Vienna Standard Mean Ocean Water (VSMOW). Routine isotopic measurements of in-house standards and samples have an overall precision of 0.2 and $1 \%$ for oxygen and hydrogen, respectively.

\subsection{Determination of watertypes and mineral saturation indices}

The results of the physical-chemical analysis were uploaded to AquaChem where water types were determined. Phreeqc version 2 was used to calculate mineral saturation indices and the partial pressure of $\mathrm{CO}_{2}\left(\mathrm{pCO}_{2}\right)$ using $\mathrm{pH}, \mathrm{DIC}, \mathrm{Ca}^{2+}$ and temperature (Parkhurst and Appelo, 1999). 


\section{CHAPTER 4}

\subsection{Results}

\subsection{Physical parameters}

Summary statistics of the results are presented in Table 1, while results of the physical, chemical and isotopic parameters are presented in Table 2.The $\mathrm{pH}$ of groundwater ranged from 6.8 to 7.2 and averaged $6.9 \pm 0.2$. The $\mathrm{pH}$ of lake water samples was more alkaline which ranged from 8.4 to 8.8 and averaged $8.6 \pm 0.2$. Stream water samples had an average $\mathrm{pH}$ of $7.5 \pm 0.2$ and ranged from 7.4 to 7.9 .

Table 1: Summary statistics of the physical and chemical compositions of water samples. All values are in $\mathrm{mg} / \mathrm{L}$ except $\mathrm{pH}$, temperature $\left({ }^{\circ} \mathrm{C}\right)$, electrical conductivity $(\mathrm{EC})(\mu \mathrm{S} / \mathrm{cm})$ and oxygen isotope $\left(\delta^{18} \mathrm{O}\right)$ and hydrogen isotopes $(\delta \mathrm{D})(\%)$. GW is groundwater, $\mathrm{LW}$ is lake water, $\mathrm{SW}$ is stream water, Minis minimum value, Max is maximum value and $\mathrm{SD}$ is the standard deviation.

\begin{tabular}{|c|c|c|c|c|c|c|c|c|c|c|c|c|c|c|c|c|c|}
\hline & & $\mathrm{pH}$ & Temp & EC & TDS & $\mathrm{Na}^{+}$ & $\mathrm{K}^{+}$ & $\mathrm{Mg}^{2+}$ & $\mathrm{Ca}^{2+}$ & $\mathrm{F}^{-}$ & $\mathrm{Cl}^{-}$ & $\mathrm{NO}_{3}{ }^{-}$ & $\mathrm{SO}_{4}^{2-}$ & $\mathrm{HCO}_{3}^{-}$ & $\mathrm{SiO}_{2}$ & $\delta^{18} \mathrm{O}$ & $\delta \mathrm{D}$ \\
\hline \multirow[t]{4}{*}{ GW } & Min & 6.8 & 27.1 & 1563 & 1000 & 52.2 & 0.4 & 13.9 & 36.4 & 0.8 & 21.3 & 27.3 & 0.2 & 286.0 & 74.0 & -6.3 & -39 \\
\hline & Max & 7.2 & 30.1 & 3497 & 2238 & 149.9 & 3.4 & 42.1 & 122.4 & 39.5 & 134.7 & 59.3 & 21.9 & 428.0 & 110.0 & -4.7 & -28 \\
\hline & Mean & 6.9 & 28.1 & 2450 & 1568 & 92.8 & 1.5 & 28.9 & 79.8 & 11.1 & 78.5 & 41.4 & 6.2 & 344.7 & 91.5 & -5.8 & -35 \\
\hline & $\mathrm{SD}$ & 0.2 & 0.9 & 604 & 387 & 33.3 & 0.9 & 7.1 & 25.2 & 11.8 & 38.1 & 12.3 & 6.1 & 40.7 & 9.4 & 0.5 & 3 \\
\hline \multirow[t]{4}{*}{ LW } & Min & 8.4 & 27.3 & 3001 & 1921 & 319.0 & 12.0 & 6.0 & 17.4 & 40.4 & 320.3 & 14.1 & 17.0 & 253.0 & 91.0 & 7.5 & 33 \\
\hline & Max & 8.8 & 27.8 & 3589 & 2297 & 338.0 & 12.7 & 10.7 & 20.6 & 42.0 & 363.2 & 18.8 & 19.7 & 297.1 & 93.0 & 9.5 & 45 \\
\hline & Mean & 8.6 & 27.5 & 3313 & 2121 & 328.4 & 12.4 & 7.9 & 19.0 & 41.4 & 343.0 & 16.3 & 18.2 & 275.5 & 92.0 & 8.5 & 40 \\
\hline & SD & 0.2 & 0.3 & 296 & 189 & 9.5 & 0.4 & 2.3 & 2.0 & 0.9 & 22.0 & 2.4 & 1.4 & 22.1 & 1.0 & 0.5 & 6 \\
\hline \multirow[t]{4}{*}{ SW } & Min & 7.4 & 22.3 & 1350 & 553 & 10.6 & 3.0 & 1.3 & 1.8 & 0.6 & 2.4 & 4.0 & 0.5 & 26.2 & 47.0 & -4.8 & -30 \\
\hline & Max & 7.9 & 29.5 & 1489 & 610 & 42.2 & 12.4 & 2.3 & 3.5 & 2.6 & 8.1 & 12.6 & 10.4 & 111.0 & 89.0 & 3.5 & -14 \\
\hline & Mean & 7.5 & 23.3 & 1445 & 592 & 23.3 & 4.6 & 1.7 & 2.5 & 2.0 & 5.4 & 10.4 & 2.9 & 63.1 & 74.0 & 0.2 & -16 \\
\hline & SD & 0.2 & 3.2 & 58 & 23 & 11.6 & 3.3 & 0.5 & 0.6 & 0.8 & 2.3 & 3.6 & 4.2 & 34.9 & 16.0 & 3.3 & 20 \\
\hline
\end{tabular}

The temperature of groundwater, lake water and stream water samples ranged from 27.1 to $30.1^{\circ} \mathrm{C}, 27.3$ to $27.8^{\circ} \mathrm{C}$ and 22.3 to $29.5^{\circ} \mathrm{C}$, respectively and averaged $28.1 \pm 0.9,27.5 \pm 0.3$ and $26.4 \pm 3.2^{\circ} \mathrm{C}$, respectively. For groundwater the EC averaged $2450 \pm 604$ 
$\mu \mathrm{S} / \mathrm{cm}$ and ranged from 1563 to $3497 \mu \mathrm{S} / \mathrm{cm}$. For the lake water samples and stream water samples, the EC ranged from 3001 to 3589 and 1350 to $1489 \mu \mathrm{S} / \mathrm{cm}$, respectively and averaged $3313 \pm 296$ and $1445 \pm 58 \mu \mathrm{S} / \mathrm{cm}$, respectively. The conductance of the stream water samples might be higher than those obtained by Saka (2006) and I attribute this to be so due to time and space. I collected my samples at the beginning of the rainy season when evaporation has occurred and the volume of water has greatly reduced causing the water to be highly concentrated. 
Table 2: Results of the physical, chemical and isotopic analyses of water samples from Lake Chilwa Basin ( - = not measured).

\begin{tabular}{|c|c|c|c|c|c|c|c|c|c|c|c|c|c|c|c|c|c|c|c|c|c|c|}
\hline ;ampleID & StationID & $\mathrm{pH}$ & $\begin{array}{l}\text { Temp. } \\
\left({ }^{\circ} \mathrm{C}\right)\end{array}$ & $\begin{array}{c}\text { EC } \\
(\mu \mathrm{S} / \mathrm{cm}\end{array}$ & $\begin{array}{c}\text { TDS } \\
\text { (ppm) }\end{array}$ & $\begin{array}{l}\mathrm{Na}^{+} \\
(\mathrm{ppm})\end{array}$ & $\begin{array}{l}\mathrm{K}^{+} \\
(\mathrm{ppm})\end{array}$ & $\begin{array}{l}\mathrm{Mg}^{2+} \\
(\mathrm{ppm})\end{array}$ & $\begin{array}{l}\mathrm{Ca}^{2+} \\
(\mathrm{ppm})\end{array}$ & $\begin{array}{c}\mathrm{F}^{-} \\
(\mathrm{ppm})\end{array}$ & $\begin{array}{l}\mathrm{Cl}^{-} \\
\text {(ppm) }\end{array}$ & $\begin{array}{l}\mathrm{NO}_{3}^{-} \\
\text {(ppm) }\end{array}$ & $\begin{array}{l}\mathrm{SO}_{4}{ }^{2-} \\
(\mathrm{ppm})\end{array}$ & $\begin{array}{l}\mathrm{HCO}_{3}^{-} \\
(\mathrm{ppm})\end{array}$ & $\begin{array}{l}\mathrm{SiO}_{2} \\
\text { (ppm) }\end{array}$ & $\begin{array}{l}\text { DIC } \\
(\mathrm{mg} \\
\mathrm{C} / \mathrm{l}) \\
\end{array}$ & $\begin{array}{l}\delta^{18} \mathrm{O} \\
(\% 0)\end{array}$ & $\begin{array}{l}\delta^{2} \mathrm{H} \\
(\% 0)\end{array}$ & $\begin{array}{c}\text { SI } \\
\text { calcite }\end{array}$ & $\begin{array}{c}\text { SI } \\
\text { dolomite }\end{array}$ & $\begin{array}{c}\text { SI } \\
\text { gypsum }\end{array}$ & $\begin{array}{l}\mathrm{pCO}_{2} \\
\text { (atm) }\end{array}$ \\
\hline Pt $1 \mathrm{BH}$ & Dzinja & 6.88 & 27.1 & 2861 & 1831 & 149.9 & 0.7 & 28.9 & 122.4 & 25.4 & 134.7 & 37.7 & 2.6 & 417.9 & 74 & 115 & -6.3 & -38 & -0.4 & -0.7 & -2.9 & -4.3 \\
\hline Pt $2 \mathrm{BH}$ & Namthiya & 6.84 & 27.3 & 2780 & 1779 & 126.2 & 1.7 & 34.1 & 119.2 & 5.56 & 130.3 & 35.4 & 9.5 & 488.0 & 99 & 189 & -6.3 & -37 & -0.2 & -0.6 & -2.7 & -4.4 \\
\hline Pt $3 \mathrm{BH}$ & Thumbulu & 6.93 & 30.1 & 2869 & 1836 & 138.2 & 2.7 & 19.3 & 88.8 & 15.2 & 132.6 & 57.4 & 10.3 & 381.9 & 79 & 121 & -6.1 & -35 & -0.1 & -0.6 & -2.6 & -4.3 \\
\hline Pt 4 BH & Nambwale & 6.78 & 28.9 & 1948 & 1247 & 115.7 & 0.8 & 36.7 & 122.2 & 11.4 & 129.3 & 59.3 & 13.5 & 341.6 & 93 & 109 & -6.0 & -35 & -0.1 & -0.6 & -2.7 & -4.2 \\
\hline Pt $5 \mathrm{BH}$ & Namuli & 6.71 & 28.2 & 3497 & 2238 & 95.0 & 2.1 & 42.1 & 80.0 & 32.1 & 104.5 & 41.6 & 6.8 & 390.3 & 95 & 148 & -6.0 & -36 & 0.0 & -0.2 & -2.8 & -4.6 \\
\hline Pt 6 BH & Chambeni & 7.10 & 28.9 & 3206 & 2052 & 128.7 & 1.8 & 25.8 & 76.4 & 17.1 & 96.8 & 56.7 & 9.5 & 357.1 & 101 & 199 & -6.1 & -38 & -0.2 & -0.5 & -2.7 & -5.5 \\
\hline Pt 7 BH & Nanthenga & 6.85 & 28.5 & 2815 & 1802 & 130.7 & 1.7 & 32.4 & 100.2 & 39.5 & 76.0 & 28.9 & 1.3 & 313.9 & 103 & 210 & -5.9 & -36 & -0.2 & -0.6 & -3.8 & -4.3 \\
\hline Pt 8 BH & Mandawala & 7.11 & 29.8 & 3100 & 1984 & 61.7 & 1.9 & 33.9 & 66.2 & 5.8 & 62.6 & 59.0 & 4.7 & 326.4 & 110 & 208 & - & - & -0.2 & -0.4 & -3.0 & -4.5 \\
\hline Pt 9 BH & Migowi & 6.82 & 27.9 & 1755 & 1123 & 82.2 & 1.8 & 13.9 & 68.4 & 1.1 & 47.8 & 58.6 & 1.1 & 322.4 & 95 & 146 & - & - & -0.4 & -1.0 & -3.7 & -4.3 \\
\hline Pt $10 \mathrm{BH}$ & Likapa & 7.06 & 27.6 & 1563 & 1000 & 75.7 & 0.4 & 28.0 & 80.4 & 3.1 & 77.2 & 31.4 & 0.3 & 286.0 & 84 & 131 & _- & - & -0.5 & -0.8 & -4.3 & -4.4 \\
\hline Pt 11 BH & Govala & 6.79 & 27.0 & 1610 & 1030 & 66.9 & 2.0 & 20.2 & 67.5 & 0.8 & 61.4 & 34.6 & 0.8 & 316.8 & 91 & 135 & -5.6 & -33 & -0.5 & -1.1 & -3.9 & -4.1 \\
\hline Pt 12 BH & Kachoka & 6.88 & 28.0 & 2359 & 1510 & 62.6 & 0.2 & 26.7 & 52.4 & 2.8 & 33.2 & 37.2 & 1.6 & 340.6 & 90 & 133 & -4.7 & -28 & -0.4 & -0.7 & -3.7 & -4.3 \\
\hline Pt $13 \mathrm{BH}$ & Pirimiti & 6.95 & 27.3 & 1962 & 1256 & 52.2 & 0.9 & 33.2 & 68.4 & 1.8 & 44.8 & 37.4 & 0.2 & 300.6 & 82 & 129 & -5.0 & -31 & -0.4 & -0.7 & -4.4 & -4.4 \\
\hline Pt 14 BH & Jali police & 7.11 & 27.8 & 2680 & 1715 & 77.1 & 0.4 & 25.3 & 36.4 & 5.7 & 54.5 & 29.9 & 11.3 & 314.7 & 92 & 140 & -5.9 & -39 & -0.3 & -0.6 & -2.7 & -0.6 \\
\hline Pt 16 BH & Lomoni & 6.70 & 27.4 & 2200 & 1408 & 52.7 & 3.4 & 33.9 & 71.6 & 5.6 & 49.6 & 27.3 & 3.0 & 336.0 & 83 & 127 & - & - & -0.4 & -0.6 & -3.3 & -3.9 \\
\hline Pt $17 \mathrm{BH}$ & Kumpalila & 7.22 & 27.5 & 1990 & 1274 & 69.9 & 1.6 & 27.7 & 55.6 & 4.7 & 21.3 & 29.3 & 21.9 & 341.6 & 93 & 142 & - & - & -0.6 & -0.8 & -2.7 & -4.6 \\
\hline Pt $1 \mathrm{SW}$ & L. Chilwa & 8.41 & 27.8 & 3589 & 2297 & 328.1 & 12.7 & 10.7 & 20.6 & 40.4 & 363.2 & 18.8 & 19.7 & 276.5 & 93 & 98 & 9.5 & 45 & -1.3 & -2.0 & -5.9 & -5.3 \\
\hline Pt 7 SW & L. Chilwa 2 & 8.78 & 27.5 & 3350 & 2144 & 338.0 & 12.4 & 7.1 & 19.0 & 42.0 & 345.5 & 16.0 & 18.0 & 297.1 & 92 & 106 & 8.5 & 33 & -1.0 & -2.2 & -3.4 & -5.5 \\
\hline Pt 8 SW & L. Chilwa 3 & 8.63 & 27.3 & 3001 & 1921 & 319.0 & 12.0 & 6.0 & 17.4 & 41.8 & 320.3 & 14.1 & 17.0 & 253.0 & 91 & 94 & 7.5 & 21 & -1.4 & -2.5 & -2.6 & -5.4 \\
\hline Pt 2 SW & Phalombe R & 7.52 & 28.8 & 915 & 586 & 42.2 & 3.0 & 1.3 & 1.8 & 2.6 & 8.1 & 4.0 & 10.4 & 111.0 & 78 & 85 & 3.5 & 18 & -2.2 & -4.3 & -4.0 & -4.9 \\
\hline Pt 3 SW & Sombani R & 7.42 & 23.8 & 949 & 607 & 22.9 & 4.4 & 2.3 & 3.3 & 0.6 & 6.1 & 12.6 & 1.1 & 86.6 & 82 & 86 & 0.5 & -25 & -2.6 & -5.2 & -5.5 & -4.8 \\
\hline Pt 4 SW & Thondwe R & 7.93 & 29.5 & 941 & 602 & 20.5 & 3.9 & 2.3 & 2.3 & 2.6 & 6.6 & 11.7 & 1.3 & 39.7 & 77 & 78 & 2.8 & -14 & -2.5 & -4.9 & -4.7 & -5.1 \\
\hline Pt 5 SW & Likangala R & 7.35 & 27.4 & 864 & 553 & 20.2 & 3.1 & 2.1 & 2.5 & 2.2 & 3.8 & 11.3 & 1.4 & 51.9 & 89 & 88 & -1.0 & -27 & -1.9 & -4.1 & -4.2 & -4.7 \\
\hline Pt 6 SW & Domasi R & 7.32 & 22.3 & 953 & 610 & 10.6 & 2.5 & 1.3 & 2.8 & 2.1 & 2.4 & 12.4 & 0.5 & 26.2 & 73 & 80 & -4.8 & -30 & -1.8 & -4.9 & -4.4 & -4.6 \\
\hline
\end{tabular}


For all the groundwater samples, the average TDS concentration was $1568 \pm 387 \mathrm{mg} / \mathrm{L}$ and ranged from 1000 to $2238 \mathrm{mg} / \mathrm{L}$. TDS concentration for Lake Chilwa samples averaged $2121 \pm 189 \mathrm{mg} / \mathrm{L}$ and ranged from 1921 to $2297 \mathrm{mg} / \mathrm{L}$. For Stream water samples, the TDS averaged $592 \pm 23$ and ranged from 553 to $610 \mathrm{mg} / \mathrm{L}$. The EC and TDS results of the Lake Chilwa water seems to be much higher than those of groundwater and fresh stream water samples. This is because the lake is a sink without a surface outlet for all sediments from catchment rivers and run-offs (Mumba et al.,1999;Saka, 2006).However, the TDS concentration shown in table 2 is the measured TDS, which includes all the dissolved solutes contained in the water

\subsection{Chemical parameters}

Among the cations, the concentrations of $\mathrm{Na}^{+}, \mathrm{K}^{+}, \mathrm{Mg}^{2+}$ and $\mathrm{Ca}^{2+}$ for groundwater ranged from 52.2 to $149.9,0.4$ to $3.4,13.9$ to 42.1 and 36.4 to $122.4 \mathrm{mg} / \mathrm{L}$ and averaged $92.8 \pm$ $33.3,1.5 \pm 0.9,28.9 \pm 7.1$ and $79.8 \pm 25.2 \mathrm{mg} / \mathrm{L}$, respectively. For lake water, the concentrations of $\mathrm{Na}^{+}, \mathrm{K}^{+}, \mathrm{Mg}^{2+}$ and $\mathrm{Ca}^{2+}$ ranged from 319.0 to $338.0,12.0$ to $12.7,6.0$ to 10.7 and 17.4 to $20.6 \mathrm{mg} / \mathrm{L}$ and averaged $328.4 \pm 9.5,12.4 \pm 0.4,7.9 \pm 2.3$ and $19.0 \pm 2.0 \mathrm{mg} / \mathrm{L}$, respectively. For stream water samples, the concentrations of $\mathrm{Na}^{+}, \mathrm{K}^{+}, \mathrm{Mg}^{2+}$ and $\mathrm{Ca}^{2+}$ ranged from 10.6 to $42.2,3.0$ to $12.4,1.3$ to 2.3 and 1.8 to $3.5 \mathrm{mg} / \mathrm{L}$ and averaged $23.3 \pm 11.6$, 4.6 $\pm 3.3,1.7 \pm 0.5$ and $2.5 \pm 0.6 \mathrm{mg} / \mathrm{L}$, respectively. The order of abundance of the cations for the groundwater and the lake water samples is $\mathrm{Na}^{+}>\mathrm{Ca}^{2+}>\mathrm{Mg}^{2+}>\mathrm{K}^{+}$and $\mathrm{Na}^{+}>$ $\mathrm{Ca}^{2+}>\mathrm{K}^{+}>\mathrm{Mg}^{2+}$, respectively. The order of abundance of the cations for the stream water samples is $\mathrm{Na}^{+}>\mathrm{K}^{+}>\mathrm{Ca}^{2+}>\mathrm{Mg}^{2+}$. 
For the anions, groundwater concentrations ofF- $\mathrm{Cl}^{-}, \mathrm{NO}_{3}{ }^{-}, \mathrm{SO}_{4}{ }^{2-}$ and $\mathrm{HCO}_{3}{ }^{-}$ranged from 0.8 to $39.5,21.3$ to $134.7,27.3$ to $59.3,0.2$ to 21.9 and 286.0 to $428.0 \mathrm{mg} / \mathrm{L}$, respectively and averaged $11.1 \pm 11.8,78.5 \pm 38.1,41.4 \pm 12.3,6.2 \pm 6.1$ and $344.7 \pm 40.7 \mathrm{mg} / \mathrm{L}$, respectively. For lake water samples the concentrations ofF- $\mathrm{Cl}^{-}, \mathrm{NO}_{3}{ }^{-}, \mathrm{SO}_{4}{ }^{2-}$ and $\mathrm{HCO}_{3}{ }^{-}$ were between 40.4 to $42.0,320$ to $363,14.1$ to $18.8,17.0$ to 19.7 and 253.0 to $297.1 \mathrm{mg} / \mathrm{L}$, respectively and averaged $41.4 \pm 0.9,343 \pm 22,16.3 \pm 2.4,18.2 \pm 1.4$ and $275.5 \pm 22.1 \mathrm{mg} / \mathrm{L}$, respectively. For stream water samples the concentrations ofF- $\mathrm{Cl}^{-}, \mathrm{NO}_{3}{ }^{-}, \mathrm{SO}_{4}{ }^{2-}$ and $\mathrm{HCO}_{3}{ }^{-}$ ranged from 0.6 to $2.6,2.4$ to $8.1,4.0$ to $12.6,0.5$ to 10.4 and 26.2 to $111.0 \mathrm{mg} / \mathrm{L}$, respectively and averaged $2.0 \pm 0.8,5.4 \pm 2.3,10.4 \pm 3.6,2.9 \pm 4.2$ and $63.1 \pm 34.9 \mathrm{mg} / \mathrm{L}$, respectively. The order of abundance is $\mathrm{HCO}_{3}{ }^{-}>\mathrm{Cl}^{-}>\mathrm{NO}_{3}>\mathrm{F}^{-}>\mathrm{SO}_{4}{ }^{2-}, \mathrm{Cl}^{-}>\mathrm{HCO}_{3}>{ }^{-}>\mathrm{F}^{-}>\mathrm{SO}_{4}{ }^{2-}$ $>\mathrm{NO}_{3}{ }^{-}$and $\mathrm{HCO}_{3}>\mathrm{NO}_{3}>\mathrm{Cl}^{-}>\mathrm{SO}_{4}{ }^{2-}>\mathrm{F}^{-}$for groundwater, lake water and stream water samples, respectively.

The concentration of $\mathrm{SiO}_{2}$ in groundwater, lake water and stream water samples averaged $91.5 \pm 9.4,92.0 \pm 1.0$ and $74.0 \pm 16.0 \mathrm{mg} / \mathrm{L}$ and ranged from 74.0 to $110.0,91.0$ to 93.0 and 47.0 to $89.0 \mathrm{mg} / \mathrm{L}$, respectively. The concentration of $\mathrm{Na}^{+}, \mathrm{K}^{+}, \mathrm{F}^{-}, \mathrm{Cl}^{-}, \mathrm{SO}_{4}{ }^{2-}$ and $\mathrm{SiO}_{2}$ is highest in the lake water samples than in groundwater samples and stream water samples due to same reason that Lake Chilwa is a sink with no outlet (Saka, 2006).

\subsection{Isotopic parameters}

The $\delta^{18} \mathrm{O}$ ratios for groundwater, lake water and stream water ranged from -6.3 to $-4.7,7.5$ to 9.5 and -4.8 to $3.5 \%$, respectively and averaged $-5.8 \pm 0.5,8.5 \pm 0.5$ and $0.2 \pm 3.3 \%$, respectively. The $\delta \mathrm{D}$ ratios for groundwater, lake water and stream water range from -39 to $-28,7$ to 33 and -30 to $18 \%$, respectively with averages of $-35 \pm 3,20 \pm 18$ and $-16 \pm 20$ 
$\%$, respectively. Groundwater samples show more negative values of both $\delta^{18} \mathrm{O}$ and $\delta \mathrm{D}$, whereas, lake water samples show the most positive values and stream water samples show intermediate values. 


\section{CHAPTER 5}

\subsection{Discussion}

\subsection{Water quality of groundwater and surface water}

The quality of groundwater and surface water determines its suitability for different purposes depending upon specific standards. The drinking water standards (Table 3) of the WHO (2008) and the Malawi Bureau of Standards (MBS) (MBS, 2005) was the basis for the water quality evaluation.

Table 3: Water Quality Standards. World Health Organization (WHO) Drinking Water Guidelines (WHO, 2008) and Malawi Bureau of Standards (MBS) Maximum Permissible Levels (MBS, 2005).

\begin{tabular}{llcc}
\hline Constituent & Unit & WHO Guideline & MBS Guideline \\
\hline Total dissolved solid (TDS) & $\mathrm{mg} / \mathrm{L}$ & 1000 & 1000 \\
Sodium & $\mathrm{mg} / \mathrm{L}$ & Not stated & 200 \\
Potassium & $\mathrm{mg} / \mathrm{L}$ & 10 & 10 \\
Magnesium & $\mathrm{mg} / \mathrm{L}$ & 150 & 150 \\
Calcium & $\mathrm{mg} / \mathrm{L}$ & 200 & 200 \\
Fluoride & $\mathrm{mg} / \mathrm{L}$ & 1.5 & 2 \\
Chloride & $\mathrm{mg} / \mathrm{L}$ & 250 & 250 \\
Nitrate & $\mathrm{mg} / \mathrm{L}$ & 50 & 50 \\
Sulfate & $\mathrm{mg} / \mathrm{L}$ & 400 & 400 \\
Bicarbonate & $\mathrm{mg} / \mathrm{L}$ & 300 & Not stated \\
\hline
\end{tabular}

The $\mathrm{pH}$ values of groundwater in the Lake Chilwa Basin averaged 6.9 \pm 0.2 which indicates slightly acidic and $\mathrm{pH}$ of lake water and stream water with the means of $8.6 \pm 0.2$ and $7.5 \pm 0.2$, respectively indicates that the lake water and surface water are alkaline. The $\mathrm{pH}$ values of the water in the Lake Chilwa Basin are within the maximum permissible limit of 6 to 9 as prescribed for drinking water by WHO (2008) and MBS (2005). 
Saka (2006) reported that electrical conductivity(EC) is strongly correlated with sodium ions and the major ions in Lake Chilwa are sodium, chloride and bicarbonates. The latter is responsible for the alkaline $\mathrm{pH}$ of the water (8-9).TDS for groundwater, lake water and stream water in the Lake Chilwa Basin range from 553 to $2297 \mathrm{mg} / \mathrm{L}$. As per TDS classification, groundwater and lake water is brackish (TDS $>1000 \mathrm{mg} / \mathrm{L}$ ) watertype whereas streams have fresh water type with TDS $<1000 \mathrm{mg} / \mathrm{L}$ (Freeze and Cherry, 1979). Based on the TDS concentration allowed for drinking water, all the groundwater and lake water samples of the Lake Chilwa Basin exceed the prescribed limit of $1000 \mathrm{mg} / \mathrm{L}$ (Figure 4). Stream water samples are below the MPL. High TDS concentrations decreases palatability of water and causes gastrointestinal irritation to consumers (Garg et al., 2009).

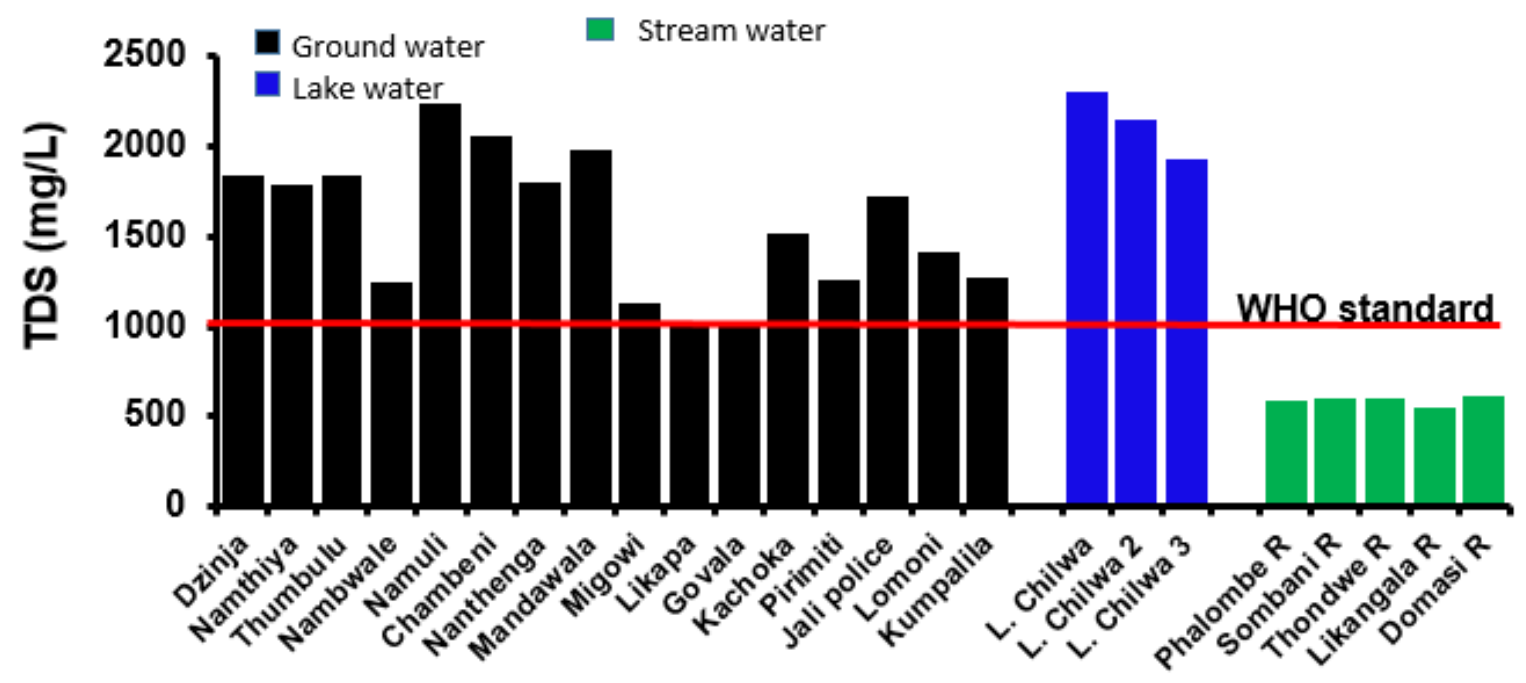

Figure 4: Plot of concentrations of total dissolved solids (TDS) for groundwater and surface water in the Lake Chilwa Basin. Also shown on the plot is a line representing World Health Organization (WHO) maximum permissible concentrations in drinking water (WHO 2008).

According to WHO (2008) and MBS (2005) guidelines, MPL for $\mathrm{Na}^{+}$in drinking water is $200 \mathrm{mg} / \mathrm{L}$. Sodium concentrations in all the groundwater and stream water samples are 
below the MPL and the concentrations of $\mathrm{Na}^{+}$in the lake water samples exceed the MPL (Figure 5a). This is consistent with earlier findings (Saka, 2006). However, $\mathrm{Na}^{+}$ concentrations are found to be higher than any other cations $\left(\mathrm{Ca}^{2+}, \mathrm{Mg}^{2+}\right.$ and $\left.\mathrm{K}^{+}\right)$in most samples. The cations $\mathrm{Na}^{+}, \mathrm{Ca}^{2+}, \mathrm{Mg}^{2+}$ and $\mathrm{K}^{+}$are significant constituents of silicate rocks (Freeze and Cherry, 1979) and hence $\mathrm{Na}^{+}$in groundwater in the Lake Chilwa Basin is considered to originate from silicate (albite) weathering. A secondary source of $\mathrm{Na}^{+}$is halite, concentrated in the soil zone by evaporation and leached into the groundwater by infiltrating rain. Elevated $\mathrm{Na}^{+}$concentrations maybe due to dissolution of sodium bicarbonate or albite. Another possible reason for the higher $\mathrm{Na}^{+}$concentration could be cation exchange where $\mathrm{Ca}^{2+}$ from groundwater is adsorbed on clay materials in exchange of $\mathrm{Na}^{+}$. Excess $\mathrm{Na}^{+}$water makes water unsuitable for drinking because it causes severe health problems like hypertension (Holden, 1970). The concentration of $\mathrm{K}^{+}$in groundwater and stream water samples is less than $10 \mathrm{mg} / \mathrm{L}$ which is the MPL as per WHO (2008) and MBS (2005). However, the concentration of $\mathrm{K}^{+}$in lake waters exceeds the MPL of $10 \mathrm{mg} / \mathrm{L}$ (Figure 5b). The low levels of $\mathrm{K}+$ in groundwater could be the consequence of its tendency to be retained in clay minerals and to contribute in the formation of secondary minerals (Zhu and Zhang, 2007). Micas (muscovite and biotite) are major constituents of the sediments / volcanic clastic sediment in the area and therefore responsible for $\mathrm{K}^{+}$in the groundwater. 

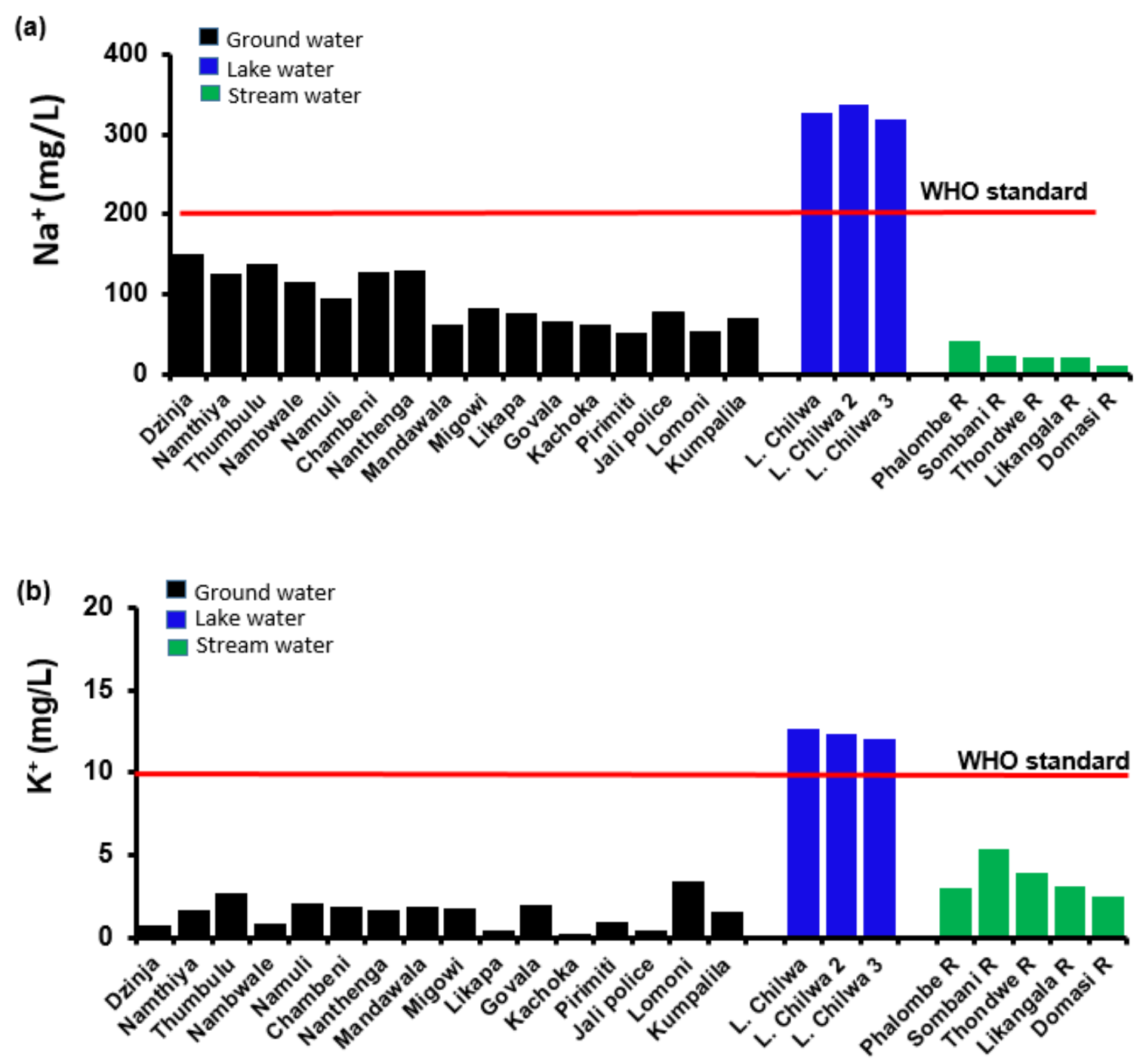

Figure 5: Plots of concentrations of cations (a) $\mathrm{Na}^{+}$and (b) $\mathrm{K}^{+}$for groundwater and surface water in the Lake Chilwa Basin. Also shown on the plot is a line representing World Health Organization (WHO)maximum permissible concentrations in drinking water (WHO, 2008).

The concentration of $\mathrm{Mg}^{2+}$ in groundwater, lake water and stream water ranges from 1.3 to $42.1 \mathrm{mg} / \mathrm{L}$ and are within the prescribed limit for drinking water specified as $150 \mathrm{mg} / \mathrm{L}$ (WHO, 2008; MBS, 2005). The $\mathrm{Mg}^{2+}$ in groundwater probably comes from biotite $\left[\mathrm{K}(\mathrm{Mg}, \mathrm{Fe})_{3}\left(\mathrm{AlSi}_{3}\right) \mathrm{O}_{10}(\mathrm{OH}, \mathrm{F})_{2}\right]$ and hornblende $\left[\mathrm{Ca}_{2}(\mathrm{MgFeAl})_{5}(\mathrm{AlSi})_{8} \mathrm{O}_{22}\right]$, which are constituents of the aquifers in the study area. All groundwater samples, lake water samples 
and stream water samples have $\mathrm{Ca}^{2+}$ concentrations below the MPL of $200 \mathrm{mg} / \mathrm{L}$ as prescribed by WHO (2008). The Ca-feldspars (anorthite) $\left(\mathrm{CaAl}_{2} \mathrm{Si}_{2} \mathrm{O}_{8}\right)$ are considered the main source of calcium, releasing $\mathrm{Ca}^{2+}$ in the presence of carbonic acid $\left(\mathrm{H}_{2} \mathrm{CO}_{3}\right)$ generated in the soil zone. Other possible sources of $\mathrm{Ca}^{2+}$ in the groundwaters include dissolution of the mineral hornblende and pyroxenes (Ganyaglo et al., 2017)

Fluoride may be an essential element for humans (WHO, 2004). Deficiency in drinking water $(<0.5 \mathrm{mg} / \mathrm{L})$ leads to dental caries (Edmunds and Smedley, 1996). High intake (>1.5 $\mathrm{mg} / \mathrm{L}$ ) results in physiological disorders, skeletal and dental fluorosis (Latha et al., 1999). Fourteen groundwater samples, all lake water samples and four stream water samples have $\mathrm{F}^{-}$concentrations that exceed the permissible limit of $1.5 \mathrm{mg} / \mathrm{L}$ and $2 \mathrm{mg} / \mathrm{L}$ as prescribed by WHO (2008) and MBS (2005), respectively as shown in figure 6(a).Elevated concentrations of F- in groundwater in the Lake Chilwa Basin may be attributed to the dissolution of the mineral apatite (Carter and Bennet, 1973).

Chloride is considered an important inorganic ion, which deteriorate the quality of drinking water (McCarthy, 2004). High concentrations of $\mathrm{Cl}^{-}$in drinking water causes a salty taste and has a laxative effect to people not accustomed to it (Bhardwaj and Singh, 2010). Generally, $\mathrm{Cl}^{-}$is not a significant constituent of silicate rocks. The presence of $\mathrm{Cl}^{-}$in groundwater and surface water is usually attributed to atmospheric sources, decomposition of organic matter and trace impurities in rocks and minerals (Freeze and Cherry, 1979). All the lake water samples exceeded the MPL of $\mathrm{Cl}^{-}$for drinking water which is specified at $250 \mathrm{mg} / \mathrm{L}$ as per WHO (2008) and MBS (2005) (Figure 6b). All groundwater and stream water samples are below the MPL for $\mathrm{Cl}^{-}$as specified by WHO (2008). 
Only five groundwater samples have exceeded the MPL of $\mathrm{NO}_{3}{ }^{-}$in drinking water which is specified as $50 \mathrm{mg} / \mathrm{L}$ as per $\mathrm{WHO}$ (2008) guidelines for drinking water and all stream water and lake water samples have $\mathrm{NO}_{3}{ }^{2}$ concentration below the $\mathrm{WHO}$ (2008) guideline standard (Figure 6c). High concentrations of $\mathrm{NO}_{3}{ }^{-}$may be due to the decaying organic matter or sewage and fertilizers used in the catchment (Karnath, 1987).High nitrate intake causes methemoglobinemia in infants, commonly known as "blue baby syndrome" (Comly, 1945). Methemoglobinemia occurs when nitrite $\left(\mathrm{NO}_{2}^{-}\right)$, a reduced form of nitrate, interacts with red blood cells and impairs their ability to carry oxygen (Mirvish, 1991). This impairment results in anoxia (deficiency of oxygen in the blood) and cyanosis (blue blood).

The concentration of $\mathrm{SO}_{4}{ }^{2-}$ is below the MPL of $400 \mathrm{mg} / \mathrm{L}$ specified by the WHO (2008) and by MBS(2005) in all the groundwater, lake water and stream water samples. Like $\mathrm{Cl}^{-}$, $\mathrm{SO}_{4}{ }^{2-}$ is not a major constituent of silicate rocks. The presence of $\mathrm{SO}_{4}{ }^{2-}$ in the aquifer may be explained by the oxidation of pyrite found in the rocks of the area. Higher concentration of $\mathrm{SO}_{4}{ }^{2-}$ in drinking water is associated with respiratory problems (Subba-Rao, 1993).

Bicarbonate $\left(\mathrm{HCO}_{3}{ }^{-}\right)$is the dominant anion in the study area. Almost all groundwater samples have $\mathrm{HCO}_{3}{ }^{-}$concentration exceeding the prescribed limit of $300 \mathrm{mg} / \mathrm{L}$ in the drinking water (WHO, 2008) (Figure 6d). All the stream water samples and lake water samples have $\mathrm{HCO}_{3}{ }^{-}$concentrations below the MPL of the WHO (2008) standard. 

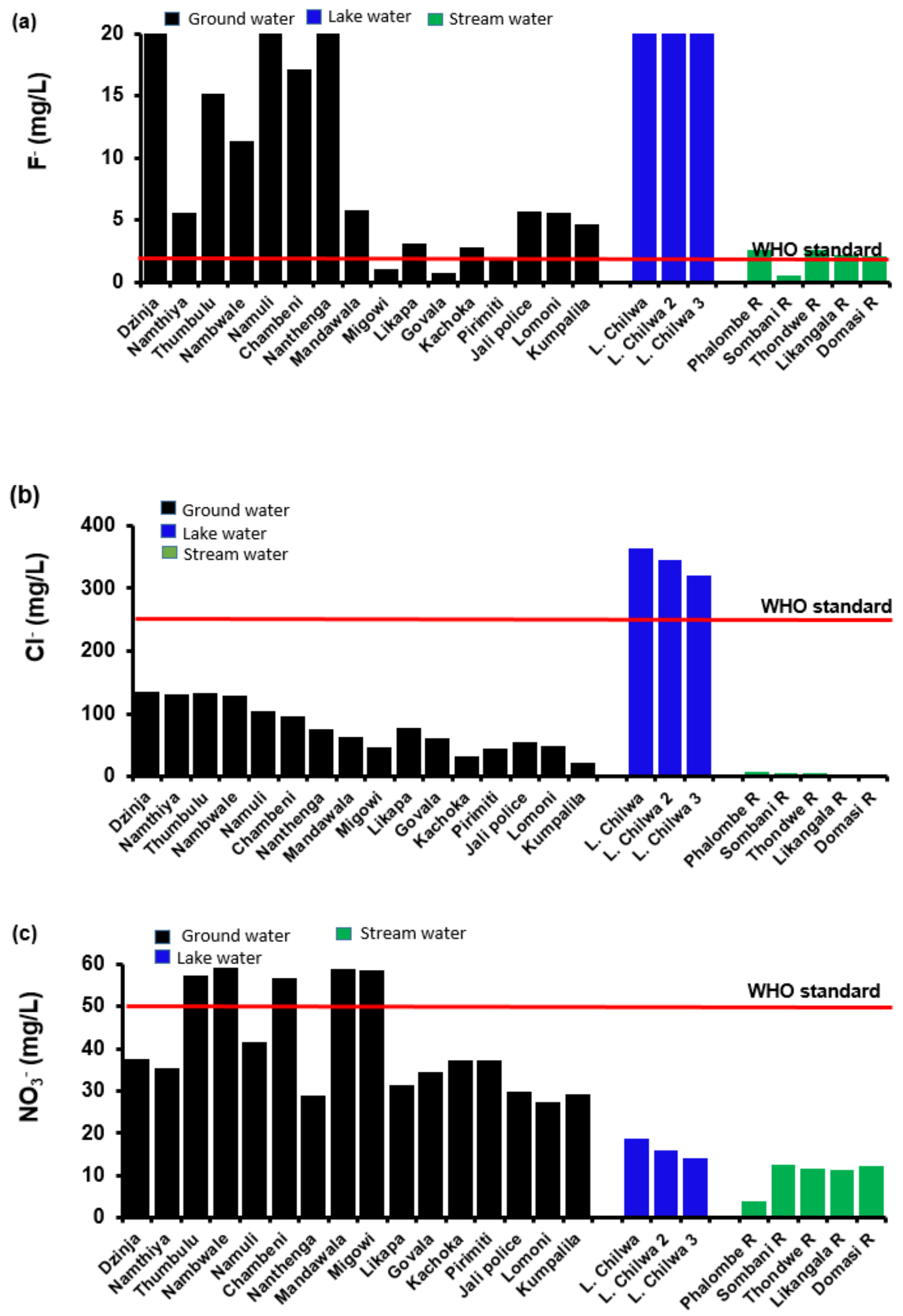


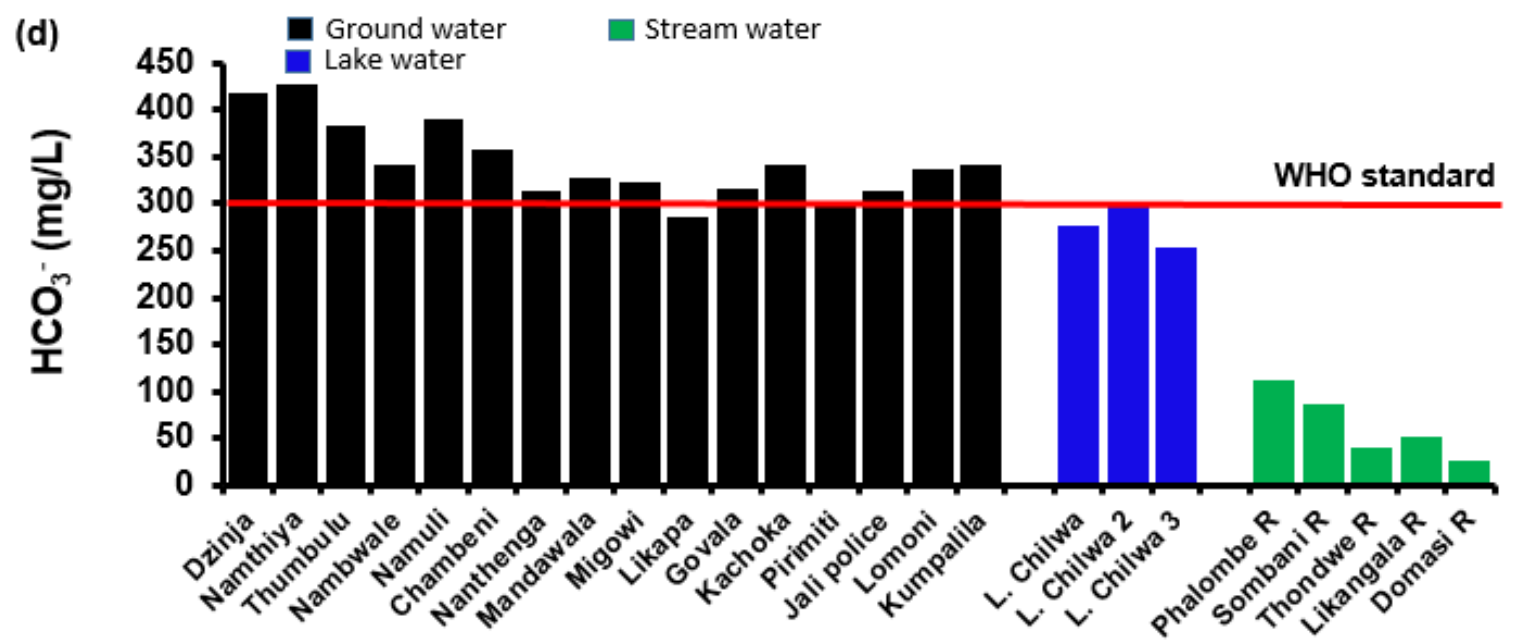

Figure 6: Plots of concentrations of (a) $\mathrm{F}^{-}$(b) $\mathrm{Cl}^{-}$, (c) $\mathrm{NO}_{3}{ }^{-}$, and (d) $\mathrm{HCO}_{3}$ - for groundwater and surface water in the Lake Chilwa Basin. Also shown on the plots are lines representing World Health Organization (WHO) maximum permissible concentrations in drinking water (WHO, 2008).

\subsection{Processes responsible for groundwater and surface water quality}

Water quality changes occur from natural water-rock interaction, from solute concentration by evaporation or from anthropogenic pollution. Water-rock interaction and evapoconcentration can be distinguished by evaluating the water for evidence of evaporation. This evidence occurs in the form of enriched stable isotopes of hydrogen and oxygen in water. The $\delta \mathrm{D}$ and $\delta^{18} \mathrm{O}$ composition of the groundwater, lake water and stream water samples are shown in Figure 7a. We also show the Global Meteoric Water Line (GMWL; Craig, 1961). We constructed a local evaporation water line (LEWL) based on the surface and lake water samples. The line has the least squares regression defined by the equation: $\delta^{2} \mathrm{H}=5.7 \delta^{18} \mathrm{O}+1.1$ and with a regression coefficient $\left(\mathrm{R}^{2}\right)$ of 0.997 that suggests a meteoric origin. The $\delta \mathrm{D}$ and $\delta^{18} \mathrm{O}$ for groundwater are more negative and mostly depleted (-39.0 to $-28.0 \%$; -6.3 to $-4.7 \%$ ) than stream water (-30.0 to $17.8 \%$; -5.1 to $2.8 \%$ ) and 
lake water samples $(-7.0$ to $33.0 \%$; 5.5 to $10.0 \%$ ). The more positive and enriched $\delta \mathrm{D}$ and $\delta^{18} \mathrm{O}$ water in lake water and stream water, and lie on the LEWL, are affected by evaporation(Clark and Fritz, 1997) (Figure 7a). The heavier $\delta \mathrm{D}$ and $\delta^{18} \mathrm{O}$ for lake water and stream water is consistent with evaporative enrichment, while in the groundwater samples, there is no evidence of evaporation as they are mostly depleted in stable isotopes and lie on GMWL (Clark and Fritz, 1997). The deviation of the surface water samples from the GMWL to the right indicates that evaporation enrichment of heavy isotope concentrations has occurred, resulting in a slope of 5.7 (Figure 6a); somewhat less than the GMWL slope(Faye, et al., 2005; Asfaw, 2010). The surface water samples are characterized by comparatively high chloride concentrations. Therefore, evaporation had an impact on the Lake Chilwa water salinity in the study area. Evaporation leads to concentration of salts $(\mathrm{NaCl})$ making the water more salty (Morgan and Kalk, 1968; Saka, 2006).

To evaluate the effect of evaporation on evapo-concentration of solutes, we plot the TDS vs. $\delta^{18} \mathrm{O}$ (Figure 7b).Enriched $\delta^{18} \mathrm{O}$ and high TDS can be attributed to evapo-concentration (e.g. Atekwana et al., 2016). There is evidence of evapo-concentration in lake water samples with high TDS and $\delta^{18} \mathrm{O}$. However, no evaporation was observed in groundwater samples hence no evidence of evapo-concentration effect on solute. Our results indicate that groundwater with high TDS and low $\delta^{18} \mathrm{O}$ can result from water-rock interaction. 

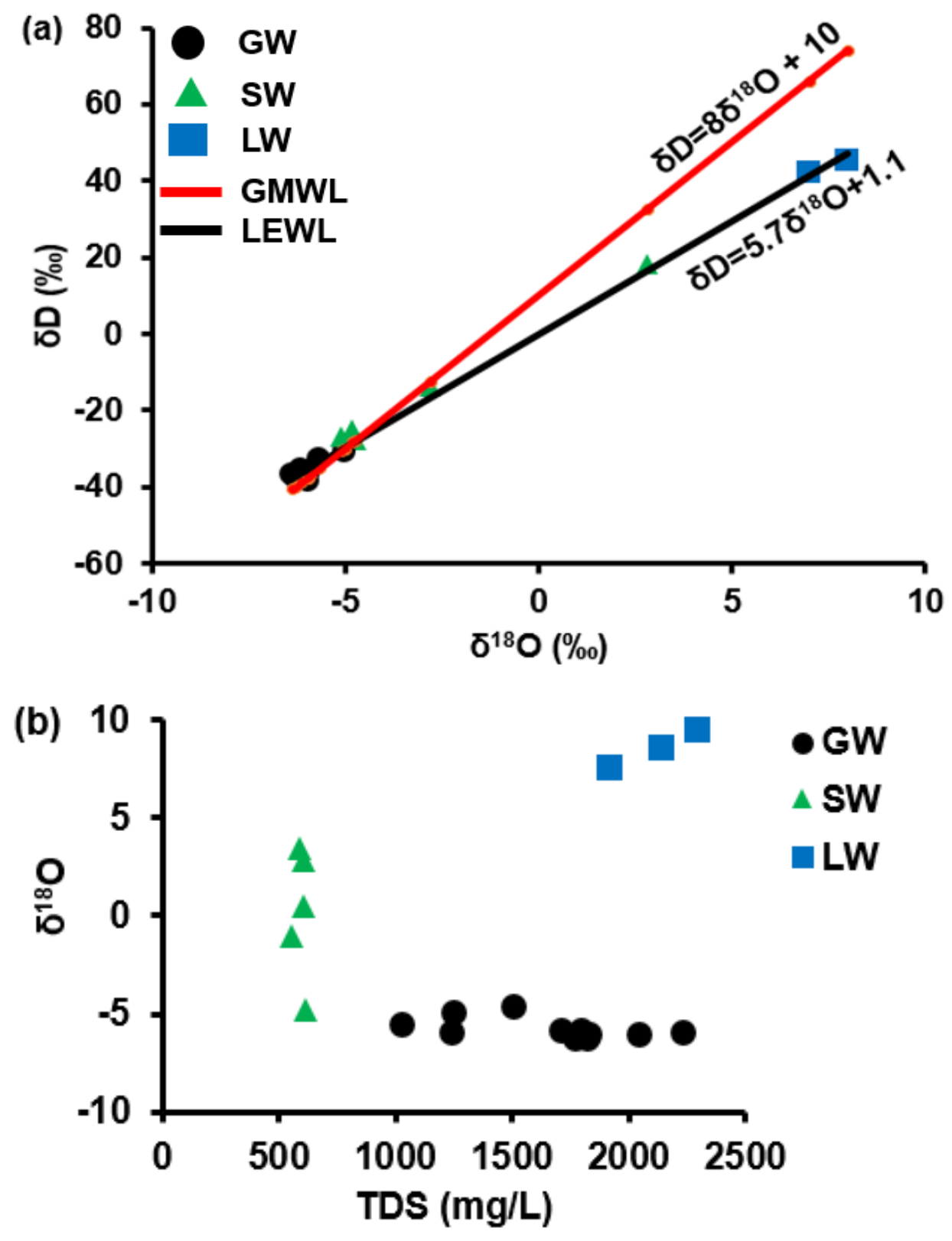

Figure 7: Cross plot of isotopic composition of (a) oxygen $\left(\delta^{18} \mathrm{O}\right)$ vs. hydrogen $\left(\delta^{2} \mathrm{H}\right)$. Also plotted is the Global Meteoric Water Line (GMWL) and the local evaporation water line (LEWL) and (b) Cross plot of isotopic composition of Total dissolved solids (TDS) vs. $\delta^{18}$ O.for groundwater and surface water in the Lake Chilwa Basin.

\subsection{Ionic evolution of groundwater and surface waters}


The piper diagram (Figure 8) shows the relative proportions of cations and anions of three distinct water types shown in grouping. The water types have facies of : (A) Na+K-HCO3, (B) $\mathrm{Na}+\mathrm{K}-\mathrm{Cl}$, and (C) $\mathrm{Ca}-\mathrm{Mg}-\mathrm{Na}+\mathrm{K}-\mathrm{HCO} 3-\mathrm{Cl}$. Water type A consists of all stream water samples and show a range of 70 to nearly $90 \% \mathrm{Na}+\mathrm{K}$ and the anions are predominantly $\mathrm{HCO} 3>80 \%$. Watertype $\mathrm{B}$ consists of lake water and have $\mathrm{Na}+\mathrm{K}$ between 90 and $100 \%$ and anion facies dominated by $\mathrm{Cl}$ of 60 to $70 \%$. Watertype $\mathrm{C}$ consists of groundwater and is a mixed cation and mixed anion facies and has $\mathrm{Ca}^{2+}, \mathrm{Mg}^{2+}, \mathrm{Na}^{+}+\mathrm{K}^{+}$in the cation facies and mainly $\mathrm{HCO}_{3}^{-}$and $\mathrm{Cl}^{-}$in the anion faces. The cation faces has the following composition: 40 to $80 \% \mathrm{Ca}, 10$ to $35 \% \mathrm{Mg}$ and 30 to $50 \% \mathrm{Na}+\mathrm{K}$, whereas, the composition of the anion facies is 60 to nearly $90 \% \mathrm{HCO}_{3}$ and 10 to $40 \% \mathrm{Cl}$. 


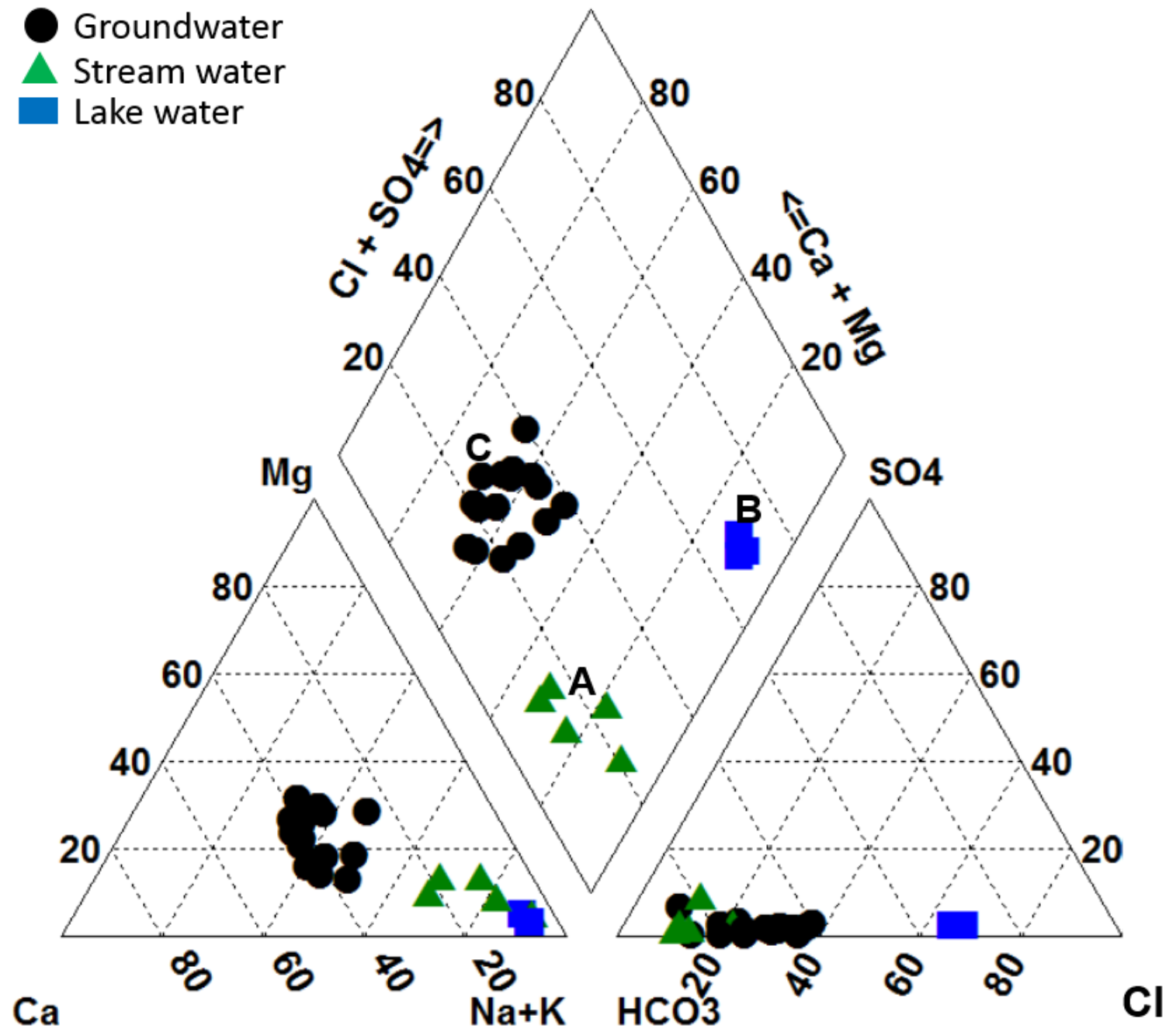

Figure 8: Piper plot showing ionic proportions for groundwater and surface water in the Lake Chilwa Basin

The chemical evolution of groundwater in crystalline basins can be attributed to water-rock interactions involving weathering of silicate minerals by $\mathrm{CO}_{2(\mathrm{~g})}$. From previous studies, silicate weathering and carbonate dissolution are viable processes controlling the variations in water quality (Wanda et al., 2013; Mapoma et al., 2016). Plagioclase weathering is probably the most important process that controls groundwater composition in the crystalline rocks resulting from the weathering of two major minerals: anorthite (An) and 
albite (Ab) (e.g., Stober and Bucher, 1998). Weathering of plagioclase leads to an increase of $\mathrm{Ca}^{2+}, \mathrm{Na}^{+}, \mathrm{HCO}_{3}^{-}$and $\mathrm{SiO}_{2}$ concentrations in groundwater (Petrides et al., 2006). Weathering of anorthite, a component of plagioclase feldspar in the presence of $\mathrm{CO}_{2(\mathrm{~g})}$ can be written as:

$3 \mathrm{H}_{2} \mathrm{O}+2 \mathrm{CO}_{2}+\mathrm{CaAl}_{2} \mathrm{Si}_{2} \mathrm{O}_{8} \rightarrow \mathrm{Al}_{2} \mathrm{Si}_{2} \mathrm{O}_{5}(\mathrm{OH})_{4}+\mathrm{Ca}^{2+}+2 \mathrm{HCO}_{3}^{-}$

Anorthite Kaolinite

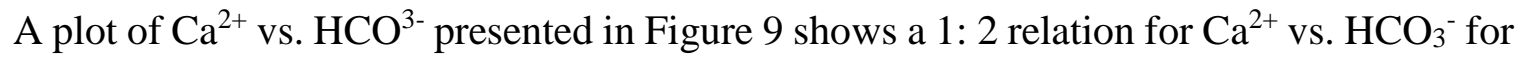
the groundwater samples indicating that $\mathrm{Ca}^{2+}$ and $\mathrm{HCO}^{3-}$ are likely derived from the weathering of anorthite. For the lake water and stream water samples, they do not fall on the $1: 2$ ratio, hence, there must be other minerals that are weathered to produce these waters or the chemical evolution of groundwater may explain their chemistry. However the data points are not in a straight line indicating that there must be contribution of other minerals.

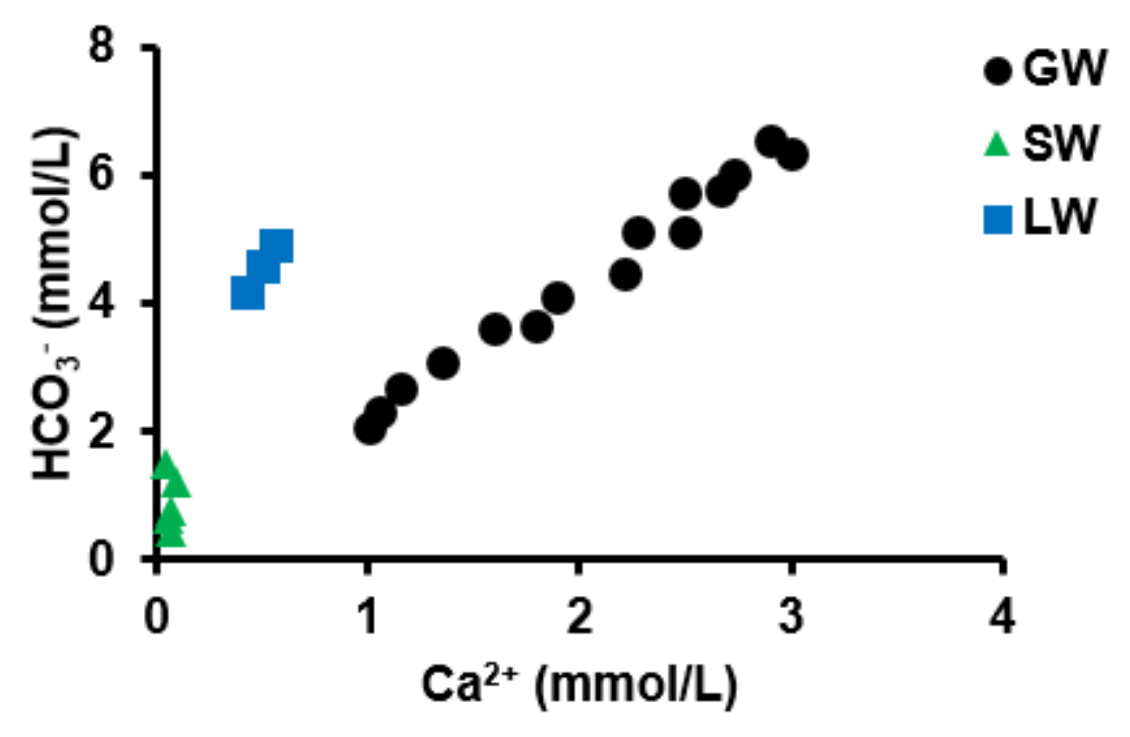

Figure 9: Cross plots of $\mathrm{Ca}^{2+}$ vs. $\mathrm{HCO}_{3}{ }^{-}$for groundwater and surface water in the Lake Chilwa Basin. 
Based on the mineralogy of the crystalline basement in the Lake Chilwa Basin, there are additional weathering reactions that can explain the concentrations of the cations in the groundwater. Granite which is one of the major rocks in the basin can contain either $\mathrm{Na}-$ rich, $\mathrm{Ca}$ - poor plagioclase or may have high $\mathrm{Ca}$ and Na poor minerals (Mast and Drever, 1990). The Ca-dominated water type can best be understood if plagioclase dissolves incongruently (Eq. 2):

$$
\begin{gathered}
3 \mathrm{H}_{2} \mathrm{O}+2 \mathrm{CO}_{2}+\mathrm{Na}_{4} \mathrm{CaAl}_{6} \mathrm{Si}_{4} \mathrm{O}_{4} \mathrm{O} \rightarrow \\
\text { Plagioclase } \\
\mathrm{Al}_{2} \mathrm{Si}_{2} \mathrm{O}_{5}(\mathrm{OH})_{4}+4 \mathrm{NaAlSi}_{3} \mathrm{O}_{8}+\mathrm{Ca}^{2+}+2 \mathrm{HCO}_{3}^{-}{ }^{-} \text {(2) } \\
\text { Kaolinite Albite }
\end{gathered}
$$

This is albitization of feldspar and secondary albite replaces plagioclase. The reaction (Eq. 2) is a description of plagioclase weathering in calcite under-saturated environments.

Weathering of biotite, which is the most abundant FeMg-mineral in most granite and gneisses of the basement, and hornblende contributes $\mathrm{Mg}$ and $\mathrm{K}$ to the solutes in waters (Mark and Bucher, 1997). At the elevated temperatures and pressures of the continental burial setting, dolomite form by reaction of calcite and magnesium silicate (Compton, 1980). The reaction proceeds as:

$$
\begin{aligned}
& \frac{1}{5} \mathrm{Mg}_{5} \mathrm{Al}_{2} \mathrm{Si}_{3} \mathrm{O}_{10}(\mathrm{OH})_{8}+\frac{4}{5} \mathrm{Al}_{2} \mathrm{Si}_{2} \mathrm{O}_{5}(\mathrm{OH})_{4}+2 \mathrm{CaCO}_{3} \rightarrow \mathrm{CaMg}\left(\mathrm{CO}_{3}\right)_{2}+\mathrm{CaAl}_{2} \mathrm{Si}_{2} \mathrm{O}_{8}+\frac{1}{5} \mathrm{SiO}_{2}+ \\
& \frac{12}{5} \mathrm{H}_{2} \mathrm{O}
\end{aligned}
$$

Figure 10 shows a 1:2 relation indicating the dissolution of dolomite in the groundwater. Dolomite dissolution is represented by the equation: 


$$
\mathrm{CaMg}\left(\mathrm{CO}_{3}\right)_{2}+2 \mathrm{H}_{2} \mathrm{O}+2 \mathrm{CO}_{2} \rightarrow \mathrm{Ca}^{2+}+\mathrm{Mg}^{2+}+4 \mathrm{HCO}_{3}^{-}
$$

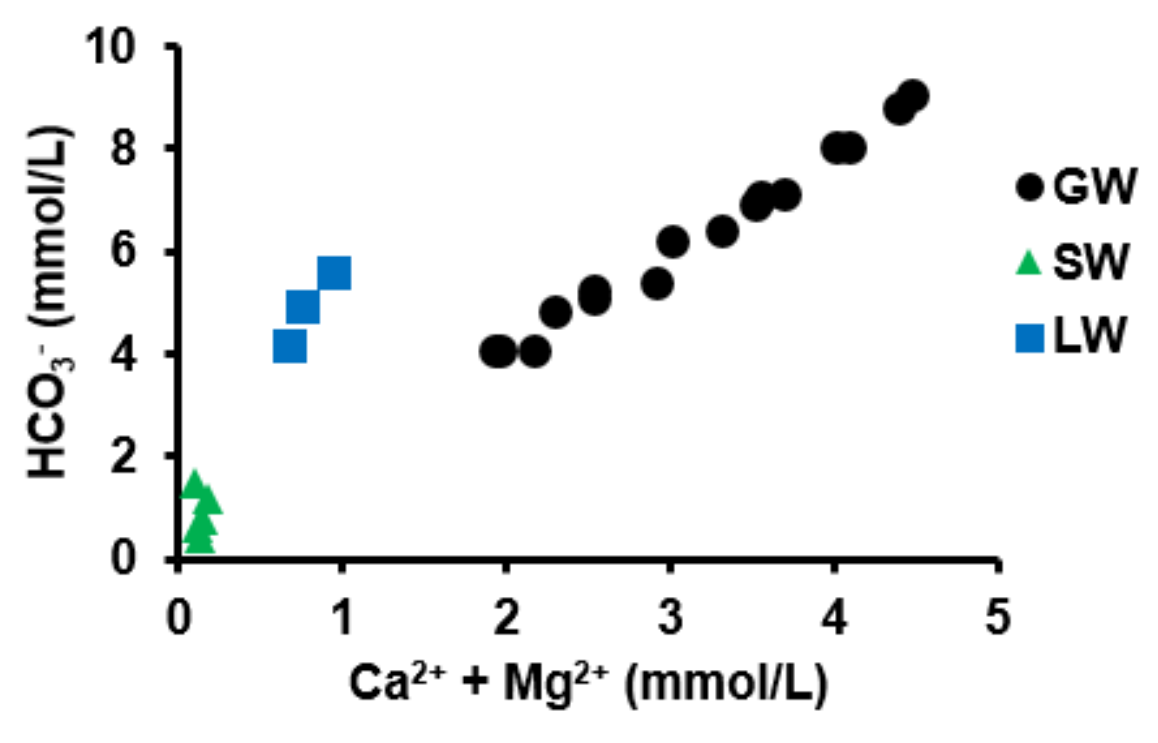

Figure 10: Cross plots of $\mathrm{Ca}^{2+}+\mathrm{Mg}^{2+}$ vs. $\mathrm{HCO}_{3}$ for groundwater and surface water in the Lake Chilwa Basin.

As the reaction progresses, water will evolve and become eventually saturated with respect to calcite. An alternative to reaction (Eq. 2) is the process of sericitization of plagioclase which produces $\mathrm{Na}$ - rich mica as a product (Blum and Stillings, 1995).

$2 \mathrm{H}_{2} \mathrm{O}+2 \mathrm{CO}_{2}+\mathrm{Na}_{4} \mathrm{CaAl}_{6} \mathrm{Si}_{4} \mathrm{O} \rightarrow \mathrm{NaAlSiO}_{10}(\mathrm{OH})_{2}+3 \mathrm{NaAlSi}_{3} \mathrm{O}_{8}+2 \mathrm{SiO}_{2}+\mathrm{Ca}^{2+}+2 \mathrm{HCO}_{3}{ }^{-}$

The high $\mathrm{Ca}$ waters could be derived by preferential weathering of anorthite rich plagioclase in more mafic rocks with low $\mathrm{X}_{\mathrm{Na}}$ (or $\mathrm{Ab}$ ) such as amphibolites and mafic gneisses.

Stream water samples can be explained by weathering of minerals in the study area. There is general increase in the silica concentrations and the dominance of $\mathrm{Na}+\mathrm{K}$ in the cation facies and $\mathrm{HCO}_{3}$ in the anion faces of stream samples which can be explained by the 
weathering of sodium and potassium rich silicates (Stallard and Edmond, 1987). For example, albite is a sodium feldspar weathers as described by the following equation:

$2 \mathrm{NaAl}_{2} \mathrm{Si}_{3} \mathrm{O}_{8}($ albite $)+2 \mathrm{CO}_{2}+11 \mathrm{H}_{2} \mathrm{O} \rightarrow \mathrm{Al}_{2} \mathrm{Si}_{2} \mathrm{O}_{5}(\mathrm{OH})_{4}+2 \mathrm{Na}^{+}+4 \mathrm{H}_{4} \mathrm{SiO}_{4}+2 \mathrm{HCO}_{3}$

Figure 11 shows a 1: 1 relation between $\mathrm{Na}^{+}$and $\mathrm{HCO}_{3}{ }^{-}$in stream water samples indicating weathering of sodium feldspar minerals. Ground water samples and lake water samples do not show a 1:1 relationship therefore have other processes controlling their ionic evolution (Jalali, 2006).

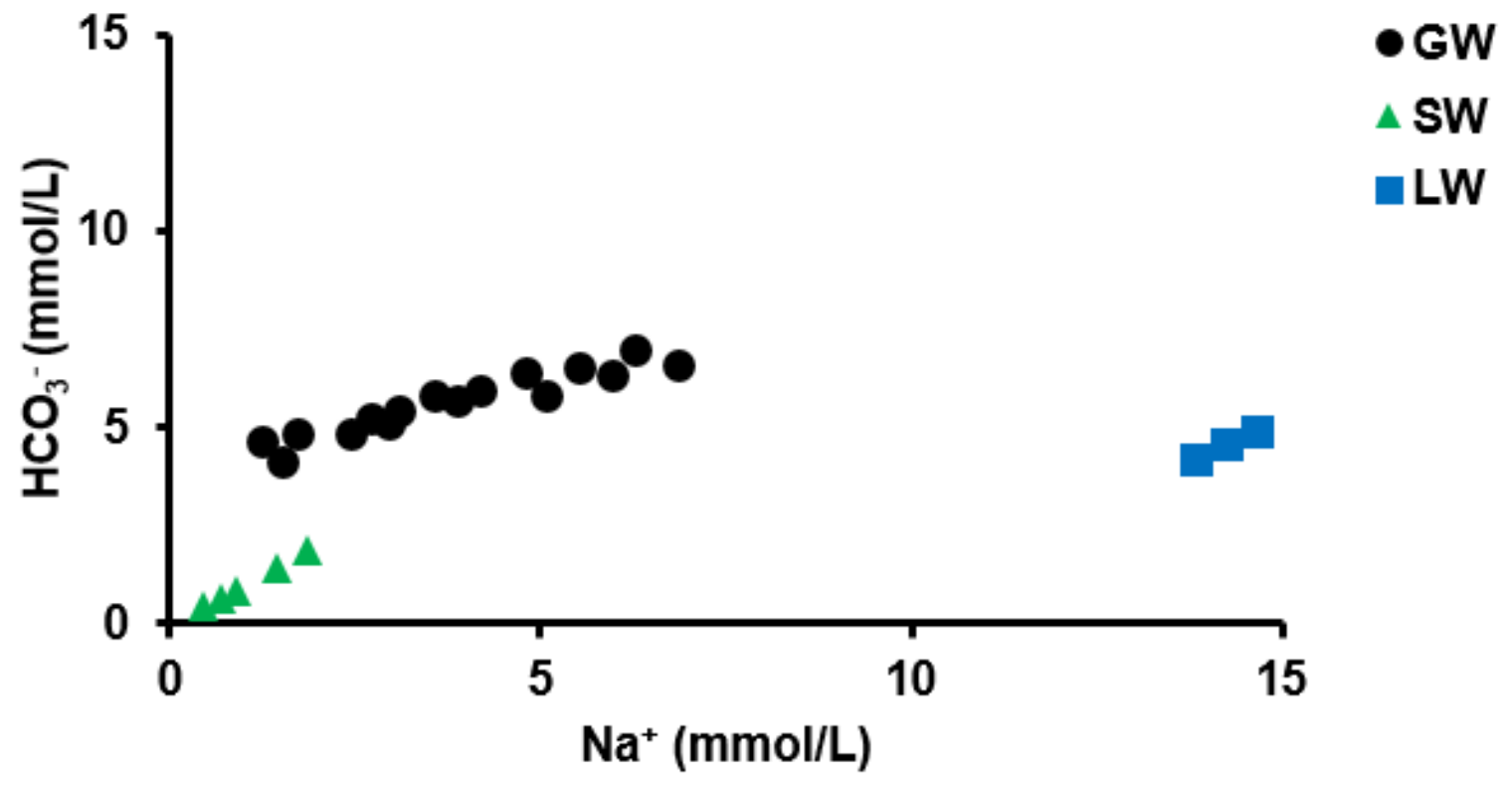

Figure 11: Cross plot of $\mathrm{Na}^{+}$vs. $\mathrm{HCO}_{3}$ for groundwater and surface water in the Lake Chilwa Basin.

Alternatively, since groundwater discharges to streams to support base flow, then the difference between groundwater and stream water can be explained by chemical evolution in the stream channel. For the concentrations of $\mathrm{Ca}^{2+}$ and $\mathrm{Mg}^{2+}$ to decrease in the stream 
water, calcite and dolomite can be precipitated. However, the equilibrium state of stream water is such that it is under-saturated as $\mathrm{SI}_{\text {calcite }}$ and $\mathrm{SI}_{\text {dolomite }}$ is $<<0$ (Table 2).

\subsection{Carbonate evolution of groundwater and surface water}

Carbonate evolution in the lake Chilwa Basin is unlikely to be influenced by the weathering of carbonates. Carbonate are not abundant in the aquifer rocks nor is it a major component of the rocks in the basin. However, during the weathering and evolution of groundwater in aquifers dominated by silicates, carbonate evolution influences how the water composition changes. For example, feldspar reacts with dilute meteoric water and forms an insoluble residual $\mathrm{Al}$-silicate mineral and a $\mathrm{Ca}-\mathrm{HCO}_{3}$ water. The weathering of the feldspar proceeds until the solution is saturated with respect to the carbonate minerals(calcite and dolomite).

From then on, plagioclase weathering reaction (Eq. 1) and the calcite equilibrium hold simultaneously:

$$
\begin{array}{r}
2 \mathrm{H}_{2} \mathrm{O}+\mathrm{CO}_{2}+\mathrm{CaAl}_{2} \mathrm{Si}_{2} \mathrm{O}_{8} \rightarrow \mathrm{Al}_{2} \mathrm{Si}_{2} \mathrm{O}_{5}(\mathrm{OH})_{4}+\mathrm{CaCO}_{3} \\
\text { Anorthite } \quad \text { Kaolinite Calcite }
\end{array}
$$

where the $\mathrm{CaCO}_{3}$ is formed by the reaction:

$$
\mathrm{Ca}^{2+}+2 \mathrm{HCO}_{3}^{-} \rightarrow \mathrm{CaCO}_{3}
$$

The supersaturation of groundwater with respect to carbonates causes calcite to precipitate in fractures and cavities and if this occurs in significant volume, may be the source of Carbonate minerals. Secondary calcite is present in fractures, veins and cavities of the granite and gneisses in the Lake Chilwa Basin (Stober and Bucher, 1998). 
The amount of $\mathrm{Ca}^{2+}$ and $\mathrm{HCO}_{3}{ }^{-}$that can be dissolved in the water largely depends on the availability of $\mathrm{CO}_{2}$. If the rocks contain carbonates and the water is not saturated with respect to calcite reaction (Eq. 9) or dolomite reaction (Eq.4) will occur and equilibrium will be reached:

$\mathrm{CaCO}_{3}+\mathrm{H}_{2} \mathrm{O}+\mathrm{CO}_{2} \rightarrow \mathrm{Ca}^{2+}+2 \mathrm{HCO}_{3}^{-}$

The saturation state of the groundwater, surface water and groundwater is shown in Figure 12. Only groundwater appears to be close to equilibrium with both calcite (Figure 12a) and dolomite (Figure 12b). As the concentrations of $\mathrm{Ca}^{2+}$ or $\mathrm{Ca}^{2+}+\mathrm{Mg}^{2+}$ increases in groundwater, the samples approach equilibrium saturation with respect to calcite (Figure 12 a) and dolomite (Figure $12 \mathrm{b)}$. 
(a)

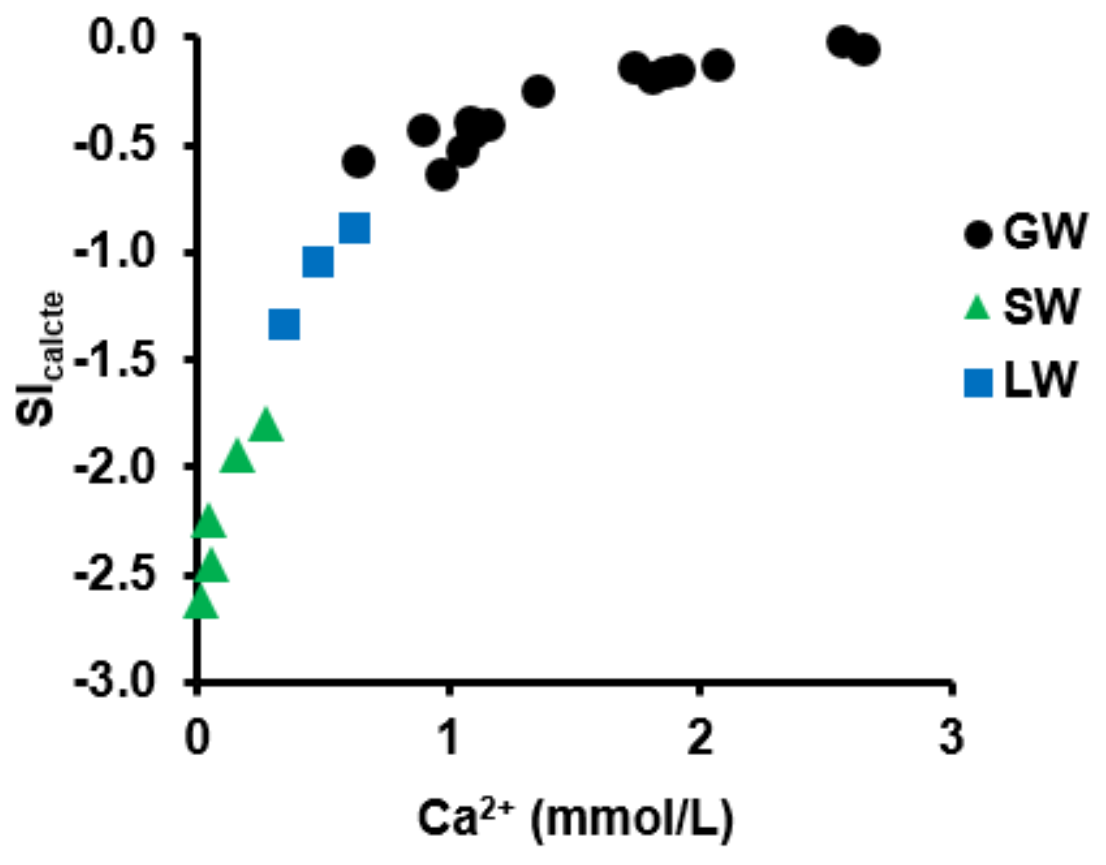

(b)

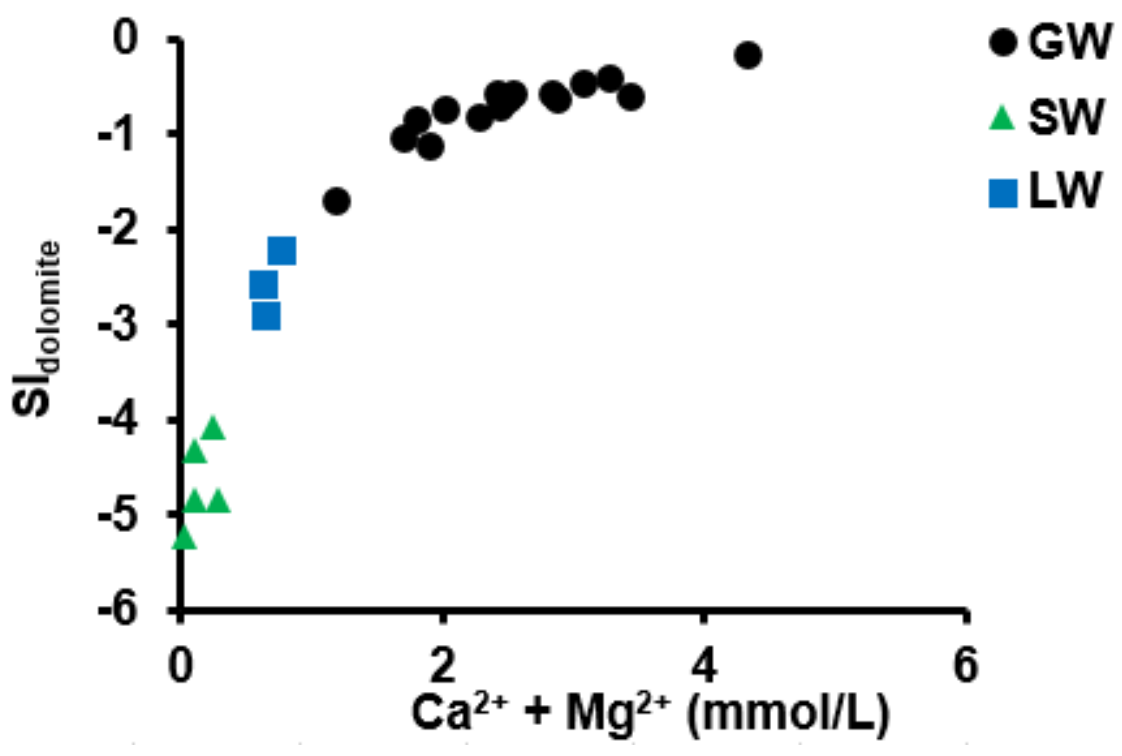

Figure 12:Cross plots of (a) $\mathrm{Ca}^{2+}$ vs the saturation index for calcite ( $\mathrm{SI}_{\text {calcite }}$ ) and (b) $\mathrm{Ca}^{2+}+\mathrm{Mg}^{2+}$ vs. saturation index for dolomite ( SI $_{\text {dolomite }}$ )for groundwater and surface water in the Lake Chilwa Basin.

The concentration of $\mathrm{CO}_{2}\left(\mathrm{pCO}_{2}\right)$ in the groundwater is extremely low $\left(\log \mathrm{pCO}_{2}=-5.5\right.$ to -3.9). This is evidence that the ability of the groundwater to both weather silicates or 
carbonated is greatly diminished. Thus, although there is the possibility of weathering carbonated from cavities and fractures in the lake Chilwa Basin, it is likely that the major cations are dominated by silicate weathering. A plot of $\mathrm{pH}$ vs. $\mathrm{pCO}_{2}$ in Figure 13 shows increase in $\mathrm{pH}$ with decrease in $\mathrm{pCO}_{2}$ which suggests that weathering has consumed the $\mathrm{CO}_{2}$ in a "closed system" evolution where $\mathrm{CO}_{2}$ is not continuously replenished as weathering proceeds (Drever, 1977).

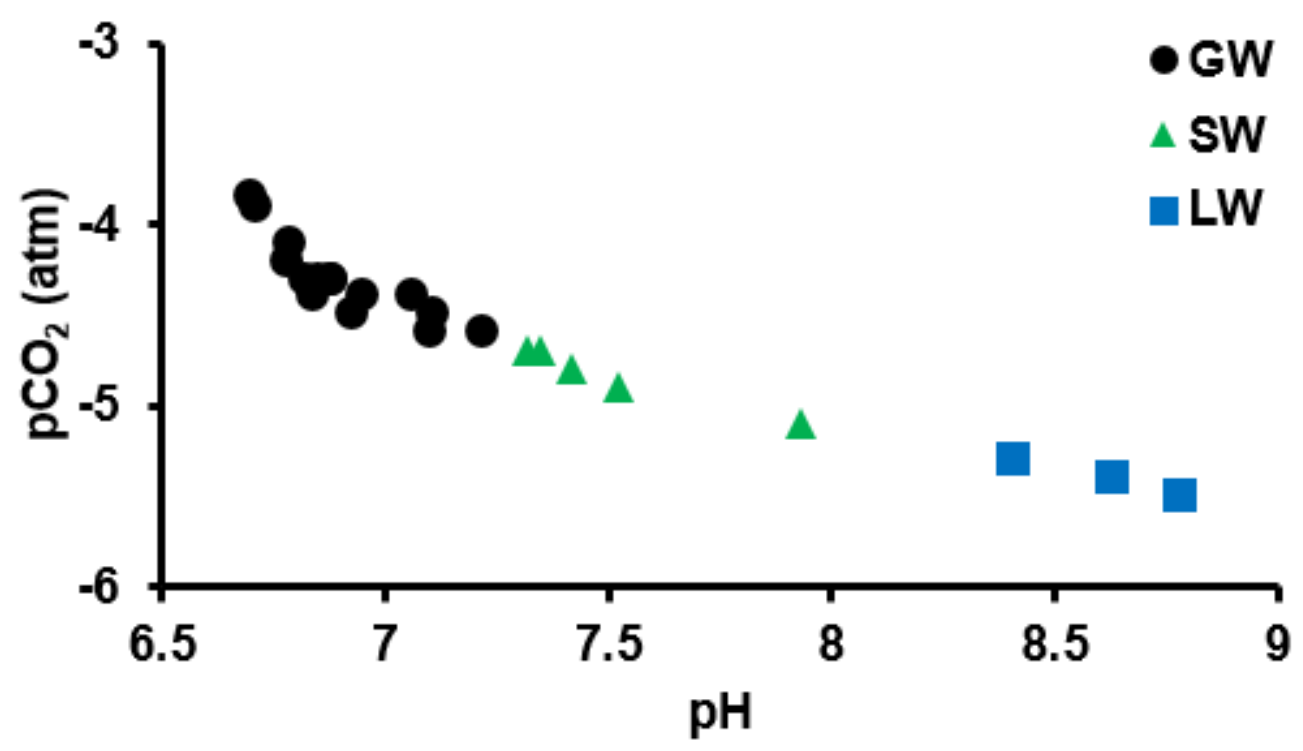

Figure 13:Cross plot of $\mathrm{pH}$ vs. $\mathrm{pCO}_{2}$ of for groundwater and surface water in the Lake Chilwa Basin 


\section{CHAPTER 6}

\subsection{Conclusions}

Hydrochemical analysis revealed that all groundwater and Lake Chilwa water in the Lake Chilwa Basin are brackish. The $\mathrm{pH}$ are slightly acidic, but mostly alkaline in nature. The major processes controlling the water quality in the Lake Chilwa Basin varies in relation to the type of water reservoir. Water-rock interaction involving weathering of silicates control the major ions such as calcium, sodium and magnesium in groundwater, whereas, evaporation is the dominant factor leading to poor water quality in the water from Lake Chilwa.

Bicarbonate $\left(\mathrm{HCO}_{3}{ }^{-}\right)$is the dominant anion in the study area. Almost all groundwater samples have $\mathrm{HCO}_{3}{ }^{-}$concentration exceeding the prescribed limit of $300 \mathrm{mg} / \mathrm{L}$ in drinking water (WHO, 2008). The occurrence of $\mathrm{Ca}^{2+}$ and $\mathrm{HCO}_{3}{ }^{-}$in groundwater causes the salty condition. The most common salt of bicarbonate is calcium bicarbonate $\left(\mathrm{Ca}\left(\mathrm{HCO}_{3}\right)_{2}\right)$. In particular, $\mathrm{Ca}\left(\mathrm{HCO}_{3}\right)_{2}$ contributes to TDS, a common parameter for assessing water quality. Lake Chilwa waters are mostly classified as sodium chloride whereas stream waters are sodium bicarbonate. Elevated $\mathrm{Na}^{+}$concentrations may be due to evaporation and probably cation exchange where $\mathrm{Ca}^{2+}$ is adsorbed on clay minerals in exchange for $\mathrm{Na}^{+}$. 
Notable characteristics of the water include high EC and high concentrations of TDS, $\mathrm{HCO}_{3}{ }^{-}, \mathrm{Cl}^{-}, \mathrm{F}^{-}$and $\mathrm{Ca}^{2+}$ in groundwater and lake water. Failure of these parameters (e.g., TDS, $\mathrm{HCO}_{3}{ }^{-}, \mathrm{Cl}^{-}, \mathrm{F}^{-}$and $\mathrm{Ca}^{2+}$ ) to comply with the $\mathrm{WHO}$ or MBS guidelines standards for drinking water signify that the some of the groundwater and lake water are of poor quality and unacceptable for human consumption without treatment.

Therefore, in general, the groundwater geochemistry of the Lake Chilwa Basin is principally controlled by water-rock interaction involving dissolution and precipitation of minerals, whereas, that of surface water, especially Lake Chilwa is controlled by evaporation and cation exchange. 


\section{CHAPTER 7}

\subsection{Future work}

The conclusions drawn from this study are the results of water chemical analysis, conducted in rainy season in Lake Chilwa Basin in Malawi. More frequent sampling (e.g., weekly to monthly) and analysis of the groundwater and surface water in the basin would allow observation of seasonal changes and assess if seasonality plays a role in the geochemical evolution of groundwater and surface water. Scouting additional boreholes, streams and various places of water points on Lake Chilwa to increase the sapling density. Conducting measurements for $\delta \mathrm{D}$ and $\delta^{18} \mathrm{O}$ and stable carbon isotopes $\left(\delta^{13} \mathrm{C}\right)$ can be used to create a more robust data set. Determining the age of the water using 14-C, would allow models to be created that assess time scale of water evolution and circulation.

The results from this study could assist decision makers understand the effects of seasonal changes on water resources and be able to apply water treatment options at the appropriate times. 


\section{REFERENCES}

Allen, D.M. and Suchy, M., 2001. Geochemical evolution of groundwater on Saturna Island, British Columbia. Canadian Journal of Earth Sciences, 38(7), pp.1059-1080.

Appelo, C.A.J., Postma, D., 2007. Geochemistry and Pollution. A.A. Balkema Publishers, TheNertherlands, 649pp.

Atekwana, E.A., Molwalefhe, L., Kgaodi, O. and Cruse, A.M., 2016. Effect of evapotranspiration on dissolved inorganic carbon and stable carbon isotopic evolution in rivers in semi-arid climates: The Okavango Delta in North West Botswana. Journal of Hydrology: Regional Studies, 7, pp.1-13.

Atekwana, E.A. and Krishnamurthy, R.V., 1998. Seasonal variations of dissolved inorganic carbon and $\delta 13 \mathrm{C}$ of surface waters: application of a modified gas evolution technique. Journal of Hydrology, 205(3-4), pp.265-278.

Atekwana, E.A. and Richardson, D.S., 2004. Geochemical and isotopic evidence of a groundwater source in the Corral Canyon meadow complex, central Nevada, USA. Hydrological Processes, 18(15), pp.2801-2815.

Atekwana, E.A. and Seeger, E.J., 2015. Carbonate and carbon isotopic evolution of groundwater contaminated by produced water brine with hydrocarbons. Applied Geochemistry, 63, pp.105-115.

Bath, A.H., 1980. Hydrochemistry in groundwater development: report on an advisory visit to Malawi, British Geological Survey Report, WD/OS/80/20

Bloomfield, K. (1965). The geology of the Zomba area. Government Printer, South Africa.

Carter, GS., Bennett, JD., 1973. The geology and mineral resources of Malawi. Geological Survey Department Bulletin, Zomba, Malawi 6, 1-62.

Chapman, D., 1992. Water quality assessment; A Guide to the use of Biota sediments and water in Environmental Monitoring. University Press, Cambridge. 
Chavula, G., \& Mulwafu, W. (2007). Hazardous water: an assessment of water quality and accessibility in the Likangala Catchment area in Malawi. Malawi Journal of Science and Technology, 8(1), 30-41.

Chidya, R. C. G., Sajidu, S. M. I., Mwatseteza, J. F., \& Masamba, W. R. L. (2011). Evaluation and assessment of water quality in Likangala River and its catchment area. Physics and Chemistry of the Earth, Parts A/B/C, 36(14-15), 865-871.

Chilton, P. J., \& Smith-Carington, A. K. (1984). Characteristics of the weathered basement aquifer in Malawi in relation to rural water supplies (pp. 57-65). IAHS Press.

Chimphamba, J., Ngongondo, C. and Mleta, P., 2009. Groundwater chemistry of basement aquifers: A case study of Malawi. The Basement Aquifers of Southern Africa, p.39.

Clark, I. D. (1997). Tracing the hydrological cycle. Environmental isotopes in hydrogeology, 3561.

Compton, J. S. (1988). Degree of supersaturation and precipitation of organogenic dolomite. Geology, 16(4), 318-321.

Craig, H. (1961). Isotopic variations in meteoric waters. Science, 133(3465), 1702-1703.

Deutsch, W.J. and Siegel, R., 1997. Groundwater geochemistry: fundamentals and applications to contamination. CRC press.

Drever, J.I., 1997. The Geochemistry of Natural Waters: Surface and Groundwater Environments. Prentice Hall. Eaglewood Cliffs, New Jersy, USA.

Ebrahimi, P. and Vilcáez, J., 2018. Effect of brine salinity and guar gum on the transport of barium through dolomite rocks: Implications for unconventional oil and gas wastewater disposal. Journal of environmental management, 214, pp.370-378.

Ebrahimi, P. and Vilcáez, J., 2018. Petroleum produced water disposal: Mobility and transport of barium in sandstone and dolomite rocks. Science of The Total Environment, 634, pp.1054-1063.

Edmunds, M., Smedley, P., 2005. Essentials of medical geology. Elseveiser Inc. Chapter 12, Oxford: BGS, NERC.

Edmunds, W.M., Savage, D., 1991. Geochemical characteristics of groundwater in granites and related crystalline rocks. In Downing, R.A., Wilkinson, W.B. (Eds) Applied groundwater Hydrology, a British Perspective, 199-216. Clarendon Press, Oxford, U.K.

Freeze, R.A., Cherry, J.A., 1979. Groundwater. Prentice Hall, Englewood Cliffs.

GARRELS, R.M., 1967. Genesis of some ground waters from igneous rocks. Researches in geochemistry, 2, pp.405-420. 
Garson, MS., 1960. The geology of Lake Chilwa area. Geological Survey Department Bulletin, Zomba, Malawi 12.

Gat, J.R. and Tzur, Y., 1968. Modification of the isotopic composition of rainwater by processes which occur before groundwater recharge. Weizmann Inst. of Science, Rehovoth, Israel.

Gibbs, R.J., 1970. Mechanisms controlling world water chemistry. Science, 170(3962), pp.10881090.

Von Hellens, A., 2013. Groundwater quality of Malawi-fluoride and nitrate of the ZombaPhalombe plain. First Cycle, G2E. Dept. of Soil and Environment. Uppsala, Sweden: Swedish University of Agricultural Sciences.

Jalali, M., 2006. Chemical characteristics of groundwater in parts of mountainous region, Alvand, Hamadan, Iran. Environmental Geology, 51(3), pp.433-446.

Kramer JR., 1968. Mineral-water equilibria in silicate weathering. In: Kantor J (ed) Rep XXIII Int+Geol Congr, Prague, Czechoslovakia, 6:149-160.

Lancaster, N., 1979. The physical environment of Lake Chilwa. In Lake Chilwa (pp. 17-40). Springer, Dordrecht.

Macuiane, M.A., Kaunda, E.K. and Jamu, D., 2011. Seasonal dynamics of physico-chemical characteristics and biological responses of Lake Chilwa, southern Africa. Journal of Great Lakes Research, 37, pp.75-82.

Malawi Bureau of Standards (MBS, 2005b) Malawi standard; drinking water-specifications. Malawi Standards Board. MS 214:2005. ICS 13.030.40 (first revision).

Mapoma, H.W. and Xie, X., 2014. Basement and alluvial aquifers of Malawi: An overview of groundwater quality and policies. African Journal of Environmental Science and Technology, 8(3), pp.190-202.

Marfia, A.M., Krishnamurthy, R.V., Atekwana, E.A. and Panton, W.F., 2004. Isotopic and geochemical evolution of ground and surface waters in a karst dominated geological setting: a case study from Belize, Central America. Applied Geochemistry, 19(6), pp.937946.

Markl, G. and Bucher, K., 1997. Reduction of Cu2+ in mine waters by hydrolysis of ferrous sheet silicates. European Journal of Mineralogy, pp.1227-1236.

Mast, M.A., Drever, J.I. and Baron, J., 1990. Chemical weathering in the Loch Vale watershed, Rocky Mountain National Park, Colorado. Water Resources Research, 26(12), pp.29712978. 
Mathess G., 1982. The properties of groundwater. Wiley, New York.

McCarthy, T.S. and Ellery, W.N., 1994. The effect of vegetation on soil and ground water chemistry and hydrology of islands in the seasonal swamps of the Okavango Fan, Botswana. Journal of Hydrology, 154(1-4), pp.169-193.

McFarlane, M.J. and Bowden, D.J., 1992. Mobilization of aluminium in the wathering profiles of the African surface in Malawi. Earth Surface Processes and Landforms, 17(8), pp.789805.

Meybeck, M., 1987. Global chemical weathering of surficial rocks estimated from river dissolved loads. American journal of science, 287(5), pp.401-428.

Mkandawire, T., 2008. Quality of groundwater from shallow wells of selected villages in Blantyre District, Malawi. Physics and Chemistry of the Earth, Parts A/B/C, 33(8-13), pp.807-811.

Monjerezi, M., Vogt, R.D., Aagaard, P. and Saka, J.D., 2011. Hydro-geochemical processes in an area with saline groundwater in lower Shire River valley, Malawi: an integrated application of hierarchical cluster and principal component analyses. Applied Geochemistry, 26(8), pp.1399-1413.

Njaya, FJ., 2001. Review of management measures for Lake Chilwa, Malawi: Final report 2001. United Nations University fisheries training programme, Iceland.

Petrides, B. and Cartwright, I., 2006. The hydrogeology and hydrogeochemistry of the Barwon Downs Graben aquifer, southwestern Victoria, Australia. Hydrogeology Journal, 14(5), pp.809-826.

Rajmohan, N. and Elango, L., 2004. Identification and evolution of hydrogeochemical processes in the groundwater environment in an area of the Palar and Cheyyar River Basins, Southern India. Environmental Geology, 46(1), pp.47-61.

Sajidu, S.M., Masumbu, F.F., Fabiano, E. and Ngongondo, C., 2007. Drinking water quality and identification of fluoritic areas in Machinga, Malawi. Malawi Journal of Science and Technology, 8(1), pp.42-56.

Saka, J.K., 2006. A chemical study of surface and groundwater in the Lake Chilwa Basin, Malawi. Groundwater Pollution in Africa, p.229.

Stallard, RF., Edmond, JM., 1987. Geochemistry of the Amazon 3. Weathering chemistry and limits to dissolved inputs. J Geophys Res 92: 8293-8302.

Subba Rao, N., 1998. Groundwater quality in crystalline terrain of Guntur district, Andhra Pradesh. Visakha Sci J, 2(1), pp.51-54. 
Subramani, T., Elango, L. and Damodarasamy, S.R., 2005. Groundwater quality and its suitability for drinking and agricultural use in Chithar River Basin, Tamil Nadu, India.

Environmental Geology, 47(8), pp.1099-1110.

Swanzie, A., Stubbs, M., 1972. Malawi in maps. Hodder \& Stoughton Ltd.Smith-Carington, AK., Chilton, PJ., 1983. Groundwater resources of Malawi. Departments of Lands, Valuation and Water; Republic of Malawi, Lilongwe.

Todd, D., 1980. Groundwater Hydrology, 2nd edition. Wiley, Newyork.

Wanda, E.M., Gulula, L.C. and Phiri, A., 2013. Hydrochemical assessment of groundwater used for irrigation in Rumphi and Karonga districts, Northern Malawi. Physics and Chemistry of the Earth, Parts A/B/C, 66, pp.51-59.

World Health Organization, 1996. Guidelines for drinking-water quality. Vol. 2, Health criteria and other supporting information. 


\section{APPENDICES}

Table showing charge balance, alkalinity, SI fluorite, and SI halite

\begin{tabular}{|c|c|c|c|c|}
\hline Sample ID & Station ID & $\begin{array}{l}\text { Charge } \\
\text { balance } \\
(\%)\end{array}$ & $\mathrm{SI}$ fluorite & SI halite \\
\hline Pt $1 \mathrm{BH}$ & Dzinja & 1.97 & 1.92 & -6.35 \\
\hline Pt 2 BH & Namthiya & 3.21 & 0.64 & -6.41 \\
\hline Pt $3 \mathrm{BH}$ & Thumbulu & 0.67 & 1.43 & -6.33 \\
\hline Pt 4 BH & Nambwale & 3.77 & 1.22 & -6.5 \\
\hline Pt 5 BH & Namuli & -0.87 & 2.01 & -6.6 \\
\hline Pt 6 BH & Chambeni & 4.44 & 1.47 & -6.49 \\
\hline Pt 7 BH & Nanthenga & 4.74 & 2.3 & -6.63 \\
\hline Pt 8 BH & Mandawala & 2.06 & 0.48 & -7 \\
\hline Pt 9 BH & Migowi & 3.28 & -0.91 & -6.98 \\
\hline Pt $10 \mathrm{BH}$ & Likapa & 3.38 & -0.02 & -6.84 \\
\hline Pt $11 \mathrm{BH}$ & Govala & 2.9 & -1.19 & -6.96 \\
\hline Pt $12 \mathrm{BH}$ & Kachoka & 1.63 & -0.22 & -7.26 \\
\hline Pt $13 \mathrm{BH}$ & Pirimiti & 4.31 & -0.49 & -7.13 \\
\hline Pt $14 \mathrm{BH}$ & Jali police & -3.01 & 0.25 & -6.95 \\
\hline Pt 16 BH & Lomoni & -1.87 & 0.46 & -7.16 \\
\hline Pt 17 BH & Kumpalila & 4.9 & 0.25 & -7.4 \\
\hline Pt 1 SW & L. Chilwa & -3.26 & 1.64 & -5.52 \\
\hline Pt 7 SW & L. Chilwa 2 & -2.67 & 1.65 & -5.53 \\
\hline Pt $8 \mathrm{SW}$ & L. Chilwa 3 & -1.33 & 1.62 & -5.58 \\
\hline Pt 2 SW & Phalombe R & 0.31 & -1.57 & -7.99 \\
\hline Pt 3 SW & Sombani R & 0.44 & -2.18 & -8.34 \\
\hline Pt 4 SW & Thondwe R & 0.99 & -1.43 & -8.39 \\
\hline Pt 5 SW & Likangala R & -1.16 & -1.55 & -8.64 \\
\hline Pt $6 \mathrm{SW}$ & Domasi R & -2.97 & -1.52 & -9.11 \\
\hline
\end{tabular}


VITA

Type Full Name Here

Candidate for the Degree of

Master of Science

Thesis: PHYSICAL, CHEMICAL AND ISOTOPIC CHARACTERISTICS OF GROUNDWATER AND SURFACE WATER IN THE LAKE CHILWA BASIN, MALAWI

Major Field: Geology

Biographical:

\section{Education:}

Completed the requirements for the Master of Science in Geology at Oklahoma State University, Stillwater, Oklahoma in May,2018

Completed the requirements for the Bachelor of Education Science in Chemistry at University of Malawi, Zomba, Malawi in 2006.

Experience:

- Mineral identification using petrographic microscope

- Proficiency in AQUACHEM software developed specifically for graphical, numerical and modelling of water quality data.

- Laboratory extraction of $\mathrm{CO}_{2}$ from Water/Acid reaction mixture using a multi-purpose vacuum line system.

- Qualitative sample identification mineral phases using X-Ray Diffractometer (XRD)

Professional Memberships:

- Geological Society of Malawi (2009 - present)

- Laboratory Association of Malawi (LAM) (2013 - present)

- American Association of Petroleum Geologists (AAPG) (2016 present) 